\title{
Metal-Dependent Cytotoxic and Kinesin Spindle Protein Inhibitory Activity of Ru, Os, Rh, and Ir Half-Sandwich Complexes of Ispinesib- Derived Ligands
}

Michał Łomzik, Muhammad Hanif, Aleksandra Budniok, Andrzej Błauż, Anna Makal, Daniel M. Tchón, Barbara Leśniewska, Kelvin K. H. Tong, Sanam Movassaghi, Tilo Söhnel, Stephen M. F. Jamieson, Ayesha Zafar, Jóhannes Reynisson, Błażej Rychlik, Christian G. Hartinger,* and Damian Plażuk*

Cite This: Inorg. Chem. 2020, 59, 14879-14890

Read Online

ACCESS 1

Wlll Metrics \& More

Article Recommendations

Supporting Information

ABSTRACT: Ispinesib is a potent inhibitor of kinesin spindle protein (KSP), which has been identified as a promising target for antimitotic anticancer drugs. Herein, we report the synthesis of halfsandwich complexes of $\mathrm{Ru}, \mathrm{Os}, \mathrm{Rh}$, and $\mathrm{Ir}$ bearing the ispinesibderived $N, N$-bidentate ligands $(R)$ - and ( $S$ )-2-(1-amino-2-methylpropyl)-3-benzyl-7-chloroquinazolin- $4(3 \mathrm{H})$-one and studies on their chemical and biological properties. Using the enantiomerically pure $(R)$ - and $(S)$-forms of the ligand, depending on the organometallic moiety, either the $S_{\mathrm{M}}, R$ or $R_{\mathrm{M}}, S$ diastereomers, respectively, were observed in the molecular structures of the Ru- and Os(cym) (cym $=\eta^{6}$-p-cymene) compounds, whereas the $R_{\mathrm{M}}, R$ or $S_{\mathrm{M}}, S$ diastereomers were found for the $\mathrm{Rh}$ - and $\operatorname{Ir}\left(\mathrm{Cp}^{*}\right)\left(\mathrm{C} \mathrm{p}^{*}=\eta^{5}\right.$ pentamethylcyclopentadienyl) derivatives. However, density func-

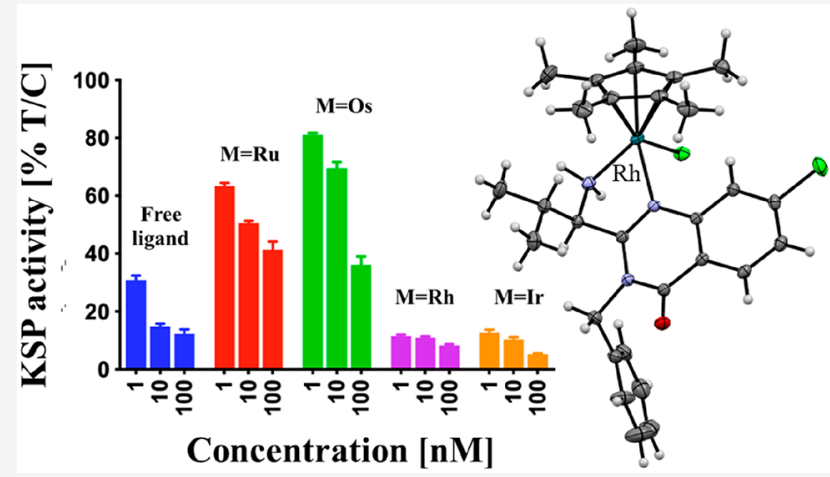
tional theory (DFT) calculations suggest that the energy difference between the diastereomers is very small, and therefore a mixture of both will be present in solution. The organometallics exhibited varying antiproliferative activity in a series of human cancer cell lines, with the complexes featuring the $(R)$-enantiomer of the ligand being more potent than the $(S)$-configured counterparts. Notably, the Rh and Ir complexes demonstrated high KSP inhibitory activity, even at $1 \mathrm{nM}$ concentration, which was independent of the chirality of the ligand, whereas the Ru and especially the Os derivatives were much less active.

\section{INTRODUCTION}

Undoubtedly, there has been considerable progress in contemporary cancer medicine, but many tumor types are still difficult to treat. Commonly used anticancer drugs, such as tubulin binding agents, taxanes (e.g., paclitaxel, docetaxel), ${ }^{1-5}$ and Vinca alkaloids (vincristine and vinblastine) ${ }^{6}$ exhibit numerous side effects. ${ }^{7}$ Therefore, it is crucial to develop new compounds exhibiting fewer or, ideally, no side effects. This can be achieved through applying a variety of strategies, such as structural modification of tubulin-binding agents or design of new low molecular weight inhibitors of proteins involved in cell division. A vast number of antimitotic agents have been synthesized ${ }^{8-12}$ or isolated from natural sources, ${ }^{13}$ and their biological properties have been extensively evaluated. To date, however, only a few semisynthetic antimitotic agents are used for cancer treatment, while others are currently in clinical trials. ${ }^{14-16}$

Mitosis, which is a strictly regulated multistep process, can be disturbed at different stages by selective inhibitors of cell cycle regulators (e.g., polo-like kinase 1, PLK1) ${ }^{17}$ or spindle checkpoint proteins (e.g., Aurora A, Aurora B, CENP-E, KSP) ${ }^{18-20}$ The therapeutic potential of inhibitors targeting aurora A (e.g., PHA-739358, MLN8237), ${ }^{18}$ aurora B (e.g., PF03814735, AZD1152), ${ }^{18}$ and PLK1 (e.g., BI2536, ON $01910)^{21,22}$ is relatively well established. Kinesins (e.g., KSP and CENPE) have been explored as molecular targets in cancer therapy since 1999, when the first low molecular weight inhibitor of a kinesin spindle protein (KSP, also known as kinesin-5 or Eg5), monastrol, was discovered. ${ }^{23} \mathrm{KSP}$ is a member of the motor proteins, playing a crucial role in spindle pole separation. It is highly active in dividing cells while almost undetectable in nondividing cells. As its inhibition results in mitotic catastrophe and leads to apoptosis, KSP is a promising

Received: March 31, 2020

Published: October 2, 2020 
molecular target for modern antimitotic anticancer drugs. A large number of structurally diverse molecules have been identified as KSP inhibitors, and some have entered clinical trials. $^{24-26}$ The most active KSP inhibitors include MK-0731, ${ }^{24}$ ARRY-649, ${ }^{27,28}$ ispinesib, ${ }^{28,29}$ and its chromone analogue SB$743921 .^{29}$

The tremendous progress in bioorganometallic chemistry has resulted in a large number of new compounds of unusual biological activity, for example, by combining organometallic compounds with biologically active molecules. ${ }^{30,31}$ Such conjugates are often more potent antiproliferative agents than their parent compounds and sometimes exhibit additional biological properties. To date, the most intensively studied derivatives are sandwich ${ }^{31}$ (mainly ferrocene and ruthenocene) and half-sandwich derivatives of $\mathrm{Ru},{ }^{32,33} \mathrm{Os},{ }^{33,34} \mathrm{Rh}^{35}$ and Ir. $^{35} \mathrm{We}$ and others studied the influence of organometallic moieties on the biological activity of antimitotic tubulinbinding agents such as taxanes, ${ }^{36,37}$ colchicine, ${ }^{38-41}$ plinabulin, ${ }^{11}$ or podophyllotoxin. ${ }^{42,43}$ We found that replacing the $N$ benzoyl moiety of paclitaxel with a ferrocenoyl moiety significantly increases its ability to induce polymerization of tubulin and the antiproliferative potency of such conjugates is higher than that of the parental taxane. ${ }^{36,37,44}$ In the case of plinabulin, we found that replacing the phenyl moiety with ferrocene leads to compounds able to inhibit clinically relevant multidrug resistance transporters $\mathrm{ABCB} 1$ and $\mathrm{ABCG} 2$. $^{11}$

The observed unexpected positive impact of an organometallic moiety on the biological activity of antimitotic agents encouraged us to study organometallic conjugates of the potent KSP inhibitor ispinesib 1. Herein, we report new halfsandwich complexes of $\mathrm{Ru}, \mathrm{Os}, \mathrm{Rh}$, and Ir bearing 2-(1-amino2-methylpropyl)-3-benzyl-7-chloroquinazolin-4(3H)-one 2 found in ispinesib as an $N, N$-bidentate ligand showing inhibitory activity of KSP and potent cytotoxic activity.

\section{EXPERIMENTAL SECTION}

Materials and Methods. All the reactions were carried out under inert conditions. All the chemicals were of analytical grade and used without further purification. Methanol and dichloromethane were dried according to standard procedures. $\mathrm{RuCl}_{3} \cdot 3 \mathrm{H}_{2} \mathrm{O}, \mathrm{OsO}_{4}, \mathrm{RhCl}_{3}$. $x \mathrm{H}_{2} \mathrm{O}$ and $\mathrm{IrCl}_{3} \cdot x \mathrm{H}_{2} \mathrm{O}$ were purchased from Precious Metals Online and Sigma-Aldrich, The dimers bis[dichlorido ( $\eta^{6}-p$-cymene)ruthenium(II) $],{ }^{45}$ bis[dichlorido( $\left(\eta^{6}-p\right.$-cymene)osmium(II) $],{ }^{46}$ bis[dichlorido $\left(\eta^{5}\right.$-pentamethylcyclopentadienyl)rhodium(III)], and bis[dichlorido $\left(\eta^{5} \text {-pentamethylcyclopentadienyl)iridium(III) }\right]^{47}$ were synthesized as described previously. The 2-(1-amino-2-methylpropyl)-3-benzyl-7-chloroquinazolin-4(3H)-one ligands $(R)-2$ and $(S)-2$ were synthesized according to a reported procedure. ${ }^{48}$

High-resolution mass spectra were recorded on a Bruker microTOF-Q II electrospray ionization (ESI) mass spectrometer in positive ion mode. Elemental analyses of the $\mathrm{Ru}, \mathrm{Rh}$, and $\mathrm{Ir}$ complexes were carried out on an Exeter Analytical Inc. CE-440 Elemental Analyzer and those of the Os complexes at the Campbell Microanalytical Laboratory, University of Otago. ${ }^{1} \mathrm{H}$ and ${ }^{13} \mathrm{C}\left\{{ }^{1} \mathrm{H}\right\}$ NMR spectra were recorded at $294 \mathrm{~K}$ on a Bruker Avance III $600 \mathrm{MHz}$ spectrometer at 600.3 MHz for ${ }^{1} \mathrm{H}$ and $150.1 \mathrm{MHz}$ for ${ }^{13} \mathrm{C}\left\{{ }^{1} \mathrm{H}\right\}$. The ${ }^{1} \mathrm{H}$ and ${ }^{13} \mathrm{C}\left\{{ }^{1} \mathrm{H}\right\}$ chemical shifts were calibrated based on the residual ${ }^{1} \mathrm{H}$ and ${ }^{13} \mathrm{C}\left\{{ }^{1} \mathrm{H}\right\}$ solvent peaks, i.e., $\delta=7.26 \mathrm{ppm}$ for ${ }^{1} \mathrm{H}$ and $77.0 \mathrm{ppm}$ for ${ }^{13} \mathrm{C}$ in $\mathrm{CDCl}_{3}$ and $\delta=5.31 \mathrm{ppm}$ for ${ }^{1} \mathrm{H}$ and $54.0 \mathrm{ppm}$ for ${ }^{13} \mathrm{C}$ in $\mathrm{CD}_{2} \mathrm{Cl}_{2}$. The UV-vis spectra were recorded at $294 \mathrm{~K}$ on a PerkinElmer Lambda 45 spectrometer. The LC-MS analyses were performed on a Shimadzu HPLC Nexera XR system with a Shimadzu LCMS-2020 detector on a Kinetex $2.6 \mu \mathrm{m}$ PS C18 $100 \AA$ column $(50 \times 2.1 \mathrm{~mm})$ using a $\mathrm{MeCN} /$ water 9:1 mixture at $0.7 \mathrm{~mL} \cdot \mathrm{min}^{-1}$ as the mobile phase.

General Procedure for the Synthesis of Ru and Os Complexes $3 a-4 b$. (S)-2 or (R)-2 was dissolved in $10 \mathrm{~mL}$ of methanol by sonication for about $5 \mathrm{~min}$. $\left[(\mathrm{cym}) \mathrm{MCl}_{2}\right]_{2}(\mathrm{M}=\mathrm{Ru}$ and $\mathrm{Os}$, cym $=$ $\eta^{6}$-p-cymene) was added in one portion to this solution, and the resulting reaction mixture was stirred overnight at $50{ }^{\circ} \mathrm{C}$. Upon the addition of $\mathrm{NH}_{4} \mathrm{PF}_{6}$, stirring was continued for another 1-2 $\mathrm{h}$, after which the solvent was removed under reduced pressure. The residue was dissolved in $20 \mathrm{~mL}$ of dry DCM, and the solution was gravity filtered to remove inorganic salts. The filtrate was reduced in volume to about $5 \mathrm{~mL}$, and about $30 \mathrm{~mL}$ hexane was added. The resulting solution was kept at $4{ }^{\circ} \mathrm{C}$ for $1-2$ days to obtain a yellow crystalline solid, which was filtered and dried to isolate pure products.

$[(\mathrm{cym}) R u\{(R)-2)\} C l]\left[\mathrm{PF}_{6}\right](3 a)$. Compound 3 was prepared in $83 \%$ yield $(497 \mathrm{mg})$ by following the general procedure using $269 \mathrm{mg}$ $(0.790 \mathrm{mmol})$ of $(R)-2,237 \mathrm{mg}(0.287 \mathrm{mmol})$ of $\left[(\mathrm{cym}) \mathrm{RuCl}_{2}\right]_{2}$, and $1.070 \mathrm{~g}(6.564 \mathrm{mmol})$ of $\mathrm{NH}_{4} \mathrm{PF}_{6} .{ }^{1} \mathrm{H} \mathrm{NMR}\left(600.3 \mathrm{MHz}, \mathrm{CDCl}_{3}, 294\right.$ $\mathrm{K}): \delta 8.49(\mathrm{~d}, J=1.9 \mathrm{~Hz}, 1 \mathrm{H}, \mathrm{H}-8), 8.26(\mathrm{~d}, J=8.5 \mathrm{~Hz}, 1 \mathrm{H}, \mathrm{H}-5)$, $7.61(\mathrm{dd}, J=8.5,1.9 \mathrm{~Hz}, 1 \mathrm{H}, \mathrm{H}-6), 7.41(\mathrm{t}, J=7.4 \mathrm{~Hz}, 2 \mathrm{H}, \mathrm{Ph})$, 7.37-7.33 (m, 3H, Ph), $6.43\left(\mathrm{t}, J=9.0 \mathrm{~Hz}, 1 \mathrm{H}, \mathrm{NH}_{2}\right), 5.99(\mathrm{~d}, J=6.1$ $\left.\mathrm{Hz}, \quad 1 \mathrm{H}, \mathrm{CH}_{3} \mathrm{C}_{6} \underline{\mathrm{H}}_{4} \mathrm{CH}\left(\mathrm{CH}_{3}\right)_{2}\right), 5.78(\mathrm{~d}, J=5.9 \mathrm{~Hz}, 1 \mathrm{H}$, $\left.\mathrm{CH}_{3} \mathrm{C}_{6} \underline{\mathrm{H}}_{4} \mathrm{CH}\left(\mathrm{CH}_{3}\right)_{2}\right), 5.70\left(\mathrm{~d}, J=15.5 \mathrm{~Hz}, 1 \mathrm{H}, \mathrm{CH}_{2}\right), 5.63(\mathrm{~d}, J=$ $\left.5.9 \mathrm{~Hz}, 1 \mathrm{H}, \mathrm{CH}_{3} \mathrm{C}_{6} \underline{\mathrm{H}}_{4} \mathrm{CH}\left(\mathrm{CH}_{3}\right)_{2}\right), 5.24(\mathrm{~d}, J=6.1 \mathrm{~Hz}, 1 \mathrm{H}$, $\left.\mathrm{CH}_{3} \mathrm{C}_{6} \underline{\mathrm{H}}_{4} \mathrm{CH}\left(\mathrm{CH}_{3}\right)_{2}\right), 5.12\left(\mathrm{td}, J=7.8,2.8 \mathrm{~Hz}, 1 \mathrm{H} \mathrm{CH}\left(\mathrm{NH}_{2}\right) \mathrm{CH}-\right.$ $\left.\left(\mathrm{CH}_{3}\right)_{2}\right), 5.10\left(\mathrm{~d}, J=16.5 \mathrm{~Hz}, 1 \mathrm{H}, \mathrm{CH}_{2}\right), 3.15(\mathrm{t}, J=8.8 \mathrm{~Hz}, 1 \mathrm{H}$, $\left.\mathrm{NH}_{2}\right), 2.62-2.57\left(\mathrm{~m}, 1 \mathrm{H}, \mathrm{CH}_{3} \mathrm{C}_{6} \mathrm{H}_{4} \mathrm{CH}\left(\mathrm{CH}_{3}\right)_{2}\right), 2.35-2.27(\mathrm{~m}, 1 \mathrm{H}$, $\left.\mathrm{CH}\left(\mathrm{NH}_{2}\right) \mathrm{CH}\left(\mathrm{CH}_{3}\right)_{2}\right), 1.55\left(\mathrm{~s}, 3 \mathrm{H}, \mathrm{CH}_{3} \mathrm{C}_{6} \mathrm{H}_{4} \mathrm{CH}\left(\mathrm{CH}_{3}\right)_{2}\right), 1.22(\mathrm{~d}, J$ $\left.=7.0 \mathrm{~Hz}, 3 \mathrm{H}, \mathrm{CH}\left(\mathrm{NH}_{2}\right) \mathrm{CH}\left(\mathrm{CH}_{3}\right)_{2}\right), 1.16(\mathrm{~d}, J=7.0 \mathrm{~Hz}, 3 \mathrm{H}$, $\left.\mathrm{CH}_{3} \mathrm{C}_{6} \mathrm{H}_{4} \mathrm{CH}\left(\mathrm{CH}_{3}\right)_{2}\right), 1.09$ (d, $J=6.9 \mathrm{~Hz}, 3 \mathrm{H}, \mathrm{CH}_{3} \mathrm{C}_{6} \mathrm{H}_{4} \mathrm{CH}-$ $\left.\left(\mathrm{CH}_{3}\right)_{2}\right), 0.51\left(\mathrm{~d}, J=6.9 \mathrm{~Hz}, 3 \mathrm{H}, \mathrm{CH}\left(\mathrm{NH}_{2}\right) \mathrm{CH}\left(\mathrm{CH}_{3}\right)_{2}\right) .{ }^{13} \mathrm{C}\left\{{ }^{1} \mathrm{H}\right\}$ NMR $\left(150.9 \mathrm{MHz}, \mathrm{CDCl}_{3}, 294 \mathrm{~K}\right): \delta 165.8(\mathrm{C}=\mathrm{O}), 159.3\left(\mathrm{C}_{\mathrm{Ar}}\right)$, $147.3\left(\mathrm{C}_{\mathrm{Ar}}\right), 142.2\left(\mathrm{C}_{\mathrm{Ar}}\right), 133.9\left(\mathrm{C}_{\mathrm{Ph}}\right), 129.7(\mathrm{C}-6), 129.5(\mathrm{C}-8)$, 129.4 (C-5), $129.2\left(\mathrm{CH}_{\mathrm{Ph}}\right), 128.4\left(\mathrm{CH}_{\mathrm{Ph}}\right), 127.5\left(\mathrm{CH}_{\mathrm{Ph}}\right), 118.8$ $\left(\mathrm{C}_{\mathrm{Ar}}\right), 104.9\left(\mathrm{C}_{\mathrm{Ar}}\right), 97.7\left(\mathrm{C}_{\mathrm{Ar}}\right), 85.2\left(\mathrm{CH}_{\mathrm{Ar}(\mathrm{Cym})}\right), 84.2\left(\mathrm{CH}_{\mathrm{Ar}(\mathrm{Cym})}\right)$, $82.4\left(\mathrm{CH}_{\mathrm{Ar}(\mathrm{Cym})}\right), 81.0\left(\mathrm{CH}_{\mathrm{Ar}(\mathrm{Cym})}\right), 67.7\left(\underline{\mathrm{CH}}\left(\mathrm{NH}_{2}\right) \mathrm{CH}\left(\mathrm{CH}_{3}\right)_{2}\right)$, $49.9\left(\mathrm{CH}_{2}\right), 33.0\left(\mathrm{CH}\left(\mathrm{NH}_{2}\right) \underline{\mathrm{CH}}\left(\mathrm{CH}_{3}\right)_{2}\right), 30.9\left(\mathrm{CH}_{3} \mathrm{C}_{6} \mathrm{H}_{4} \underline{\mathrm{CH}}-\right.$ $\left.\left(\mathrm{CH}_{3}\right)_{2}\right), 22.9\left(\mathrm{CH}_{3} \mathrm{C}_{6} \mathrm{H}_{4} \mathrm{CH}\left(\underline{\mathrm{CH}}_{3}\right)_{2}\right), 21.0\left(\mathrm{CH}_{3} \mathrm{C}_{6} \mathrm{H}_{4} \mathrm{CH}\left(\mathrm{CH}_{3}\right)_{2}\right)$, $19.2\left(\mathrm{CH}\left(\mathrm{NH}_{2}\right) \mathrm{CH}\left(\mathrm{CH}_{3}\right)_{2}\right), 17.8\left(\underline{\mathrm{CH}}_{3} \mathrm{C}_{6} \mathrm{H}_{4} \mathrm{CH}\left(\mathrm{CH}_{3}\right)_{2}\right), \quad 15.6$ $\left(\mathrm{CH}\left(\mathrm{NH}_{2}\right) \mathrm{CH}\left(\mathrm{CH}_{3}\right)_{2}\right)$. Elemental analysis calculated for $\mathrm{C}_{29} \mathrm{H}_{34} \mathrm{Cl}_{2} \mathrm{~F}_{6} \mathrm{~N}_{3} \mathrm{OPRu}(757.539 \mathrm{~g} / \mathrm{mol}): \mathrm{C}, 45.98 ; \mathrm{H}, 4.52 ; \mathrm{N}, 5.55$. Found: C, 45.82; H, 4.59; N, 5.62. ESI-MS calculated for $\mathrm{C}_{29} \mathrm{H}_{34} \mathrm{Cl}_{2} \mathrm{~N}_{3} \mathrm{ORu}\left[\mathrm{M}-\mathrm{PF}_{6}\right]^{+}, m / z: 612.1119$. Found: 612.1137.

General Procedure for the Synthesis of Rh and Ir Complexes $5 a-6 b$. A solution of 1 equiv of ligand $(R)-2$ or $(S)-2$ in an appropriate amount of methanol was added to a slurry of 0.5 equiv of $\left[(\mathrm{Cp} *) \mathrm{MCl}_{2}\right]_{2}\left(\mathrm{M}=\mathrm{Rh}\right.$ or Ir, $\mathrm{Cp}^{*}=\eta^{5}$-pentamethylcyclopentadienyl) in $5 \mathrm{~mL}$ of methanol, and the resulting solution was stirred at RT under an argon atmosphere for $1 \mathrm{~h}$. The solvent was evaporated, and the residue was dissolved in an appropriate amount of water. A saturated solution of $\mathrm{KPF}_{6}(3 \mathrm{~mL})$ in water was added to this solution. The product was extracted with dichloromethane $(3 \times 10$ $\mathrm{mL})$. The organic fractions were combined and dried over magnesium sulfate, and the solution was evaporated to dryness. The crude product was dissolved in a minimal amount of hot methanol, and the resulting solution was kept in the freezer for $48 \mathrm{~h}$ at $-30{ }^{\circ} \mathrm{C}$. Crystals of pure products were collected by filtration, washed with cold methanol, and dried.

$[(C p *) R h\{(R)-2)\} C I]\left[P F_{6}\right]$ (5a). Compound 5a was synthesized in $75 \%$ yield (171 $\mathrm{mg})$ according to the general procedure starting from $92 \mathrm{mg}(0.15 \mathrm{mmol})$ of $\left[\left(\mathrm{Cp}^{*}\right) \mathrm{RhCl}_{2}\right]_{2}$ and $103 \mathrm{mg}(0.30 \mathrm{mmol})$ of (R)-2. ${ }^{1} \mathrm{H}$ NMR $\left(600.3 \mathrm{MHz}, \mathrm{CD}_{2} \mathrm{Cl}_{2}, 294 \mathrm{~K}\right): \delta 8.29(\mathrm{~d}, J=8.6 \mathrm{~Hz}$, $1 \mathrm{H}, \mathrm{H}-5), 8.25$ (d, $J=1.6 \mathrm{~Hz}, 1 \mathrm{H}, \mathrm{H}-8), 7.64(\mathrm{dd}, J=8.5,1.7 \mathrm{~Hz}, 1 \mathrm{H}$, H-6), $7.43(\mathrm{t}, J=7.4 \mathrm{~Hz}, 2 \mathrm{H}, \mathrm{Ph}), 7.37(\mathrm{t}, J=7.3 \mathrm{~Hz}, 1 \mathrm{H}, \mathrm{Ph}), 7.34$ $(\mathrm{d}, J=7.5 \mathrm{~Hz}, 2 \mathrm{H}, \mathrm{Ph}), 5.95\left(\mathrm{~d}, J=15.3 \mathrm{~Hz}, 1 \mathrm{H}, \mathrm{CH}_{2}\right), 5.01(\mathrm{td}, J=$ 7.3, $\left.2.3 \mathrm{~Hz}, 1 \mathrm{H}, \mathrm{C} \underline{\mathrm{H}}\left(\mathrm{NH}_{2}\right) \mathrm{CH}\left(\mathrm{CH}_{3}\right)_{2}\right), 4.89(\mathrm{~d}, J=15.5 \mathrm{~Hz}, 1 \mathrm{H}$, $\left.\mathrm{CH}_{2}\right), 4.55\left(\mathrm{t}, J=8.9 \mathrm{~Hz}, 1 \mathrm{H}, \mathrm{NH}_{2}\right), 3.46\left(\mathrm{t}, J=8.2 \mathrm{~Hz}, 1 \mathrm{H}, \mathrm{NH}_{2}\right)$, $2.37-2.32\left(\mathrm{~m}, 1 \mathrm{H}, \mathrm{CH}\left(\mathrm{NH}_{2}\right) \mathrm{CH}\left(\mathrm{CH}_{3}\right)_{2}\right), 1.42\left(\mathrm{~s}, 15 \mathrm{H}, \mathrm{Cp}^{*}\right), 1.26$ $\left(\mathrm{d}, J=6.9 \mathrm{~Hz}, 3 \mathrm{H}, \mathrm{CH}\left(\mathrm{NH}_{2}\right) \mathrm{CH}\left(\mathrm{CH}_{3}\right)_{2}\right), 0.59(\mathrm{~d}, J=6.9 \mathrm{~Hz}, 3 \mathrm{H}$, $\left.\mathrm{CH}\left(\mathrm{NH}_{2}\right) \mathrm{CH}\left(\mathrm{CH}_{3}\right)_{2}\right) .{ }^{13} \mathrm{C}\left\{{ }^{1} \mathrm{H}\right\} \mathrm{NMR}\left(151.0 \mathrm{MHz}, \mathrm{CD}_{2} \mathrm{Cl}_{2}, 294 \mathrm{~K}\right)$ : $\delta 166.7(\mathrm{C}=\mathrm{O}), 160.2\left(\mathrm{C}_{\mathrm{Ar}}\right), 145.6\left(\mathrm{C}_{\mathrm{Ar}}\right), 142.6\left(\mathrm{C}_{\mathrm{Ar}}\right), 135.3\left(\mathrm{C}_{\mathrm{Ar}}\right)$, $130.2(\mathrm{C}-6), 130.2\left(\mathrm{CH}_{\mathrm{Ph}}\right), 129.9(\mathrm{C}-5), 129.5\left(\mathrm{CH}_{\mathrm{Ph}}\right), 128.2\left(\mathrm{CH}_{\mathrm{Ph}}\right.$ or C-8), $128.1\left(\mathrm{CH}_{\mathrm{Ph}}\right.$ or C-8), $120.1\left(\mathrm{C}_{\mathrm{Ar}}\right), 96.7\left(\mathrm{~d},{ }^{1} J_{\mathrm{C}-\mathrm{Rh}}=8.5 \mathrm{~Hz}\right.$, $\left.\eta^{5}-\underline{C}_{5} \mathrm{Me}_{5}\right), 65.5\left(\underline{\mathrm{CH}}\left(\mathrm{NH}_{2}\right) \mathrm{CH}\left(\mathrm{CH}_{3}\right)_{2}\right), 49.3\left(\mathrm{CH}_{2}\right), 34.1(\mathrm{CH}-$ 
Chart 1. Structure of (R)-Ispinesib 1 and Synthetic Route to Complexes $3 a-6 b$<smiles>C=CC(C)C(c1nc2cc(Cl)ccc2c(=O)n1Cc1ccccc1)N(CCCN)C(=O)c1ccc(C)cc1</smiles><smiles>CC(C)C(N)c1nc2cc(Cl)ccc2c(=O)n1Cc1ccccc1</smiles>

(R)-2 or $(S)-\mathbf{2}$

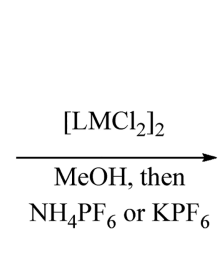

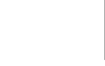

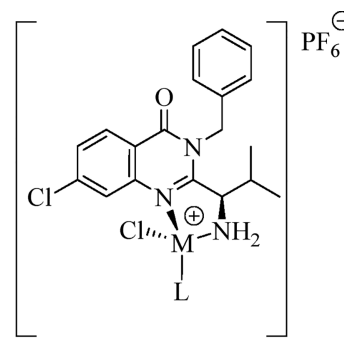

3a $\mathrm{L}=$ cym; $\mathrm{M}=\mathrm{Ru}$ 4a $\mathrm{L}=$ cym; $\mathrm{M}=\mathrm{Os}$ 5a $\mathrm{L}=\mathrm{Cp}^{*} ; \mathrm{M}=\mathrm{Rh}$ 6a $\mathrm{L}=\mathrm{Cp}^{*} ; \mathrm{M}=\mathrm{Ir}$

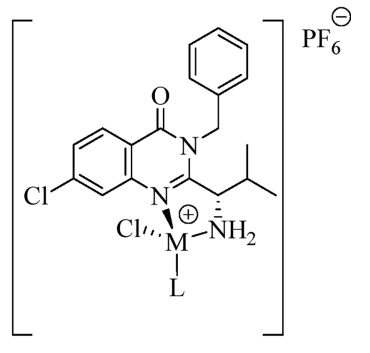

3b $\mathrm{L}=\mathrm{cym} ; \mathrm{M}=\mathrm{Ru}$ $\mathbf{4 b} \mathrm{L}=$ cym; $\mathrm{M}=\mathrm{Os}$ $\mathbf{5 b} \mathrm{L}=\mathrm{Cp}^{*} ; \mathrm{M}=\mathrm{Rh}$ $\mathbf{6 b} \mathrm{L}=\mathrm{Cp}^{*} ; \mathrm{M}=\mathrm{Ir}$
$\left.\left(\mathrm{NH}_{2}\right) \underline{\mathrm{CH}}\left(\mathrm{CH}_{3}\right)_{2}\right), 19.8\left(\mathrm{CH}\left(\mathrm{NH}_{2}\right) \mathrm{CH}\left(\mathrm{CH}_{3}\right)_{2}\right), 15.7\left(\mathrm{CH}\left(\mathrm{NH}_{2}\right)-\right.$ $\left.\mathrm{CH}\left(\mathrm{CH}_{3}\right)_{2}\right)$, $9.2\left(\mathrm{CH}_{3\left(\mathrm{Cp}^{*}\right)}\right)$. Elemental analysis calculated for $\mathrm{C}_{29} \mathrm{H}_{35} \mathrm{Cl}_{2} \mathrm{~F}_{6} \mathrm{~N}_{3} \mathrm{OPRh}(760.388 \mathrm{~g} / \mathrm{mol}): \mathrm{C}, 45.81 ; \mathrm{H}, 4.64 ; \mathrm{N}, 5.53$. Found: C, 45.51; H, 4.32; N, 5.51. ESI-MS calculated for $\mathrm{C}_{29} \mathrm{H}_{35} \mathrm{Cl}_{2} \mathrm{~N}_{3} \mathrm{ORh}\left[\mathrm{M}-\mathrm{PF}_{6}\right]^{+}, m / z: 614.1207$. Found: 614.1193. calculated for $\mathrm{C}_{29} \mathrm{H}_{34} \mathrm{ClN}_{3} \mathrm{ORh}\left[\mathrm{M}-\mathrm{HCl}-\mathrm{PF}_{6}\right]^{+}, m / z: 578.1440$. Found: 578.1435 .

\section{RESULTS AND DISCUSSION}

The half-sandwich complexes $\mathbf{3 a}-\mathbf{6} \mathbf{b}$ were synthesized in one step reactions starting from optically pure ligands $(R)-2$ for $3 \mathbf{a}-\mathbf{6 a}$ or $(S)-\mathbf{2}$ for $\mathbf{3 b}-\mathbf{6} \mathbf{b}$ and the corresponding dimetallic precursors $\left[(\mathrm{cym}) \mathrm{MCl}_{2}\right]_{2}(\mathrm{M}=\mathrm{Ru}$ for $3, \mathrm{M}=\mathrm{Os}$ for 4$)$ or $\left[\left(\mathrm{Cp}^{*}\right) \mathrm{MCl}_{2}\right]_{2}(\mathrm{M}=\mathrm{Rh}$ for $5, \mathrm{M}=\mathrm{Ir}$ for 6). All complexes were prepared in the reaction of enantiomerically pure 2 with 0.5 equiv of the corresponding dimetallic precursors in methanol at RT or $50{ }^{\circ} \mathrm{C}$ and were isolated as hexafluorophosphate salts in good to excellent yields (Chart 1). The structures of these complexes were established by NMR spectroscopy, MS, and X-ray crystallography.

The complexation of ligands $(R)-2$ and $(S)-2$ to the metal centers results in significant changes in the NMR spectra. For example, in the ${ }^{1} \mathrm{H}$ NMR spectra, the $\mathrm{H}-8$ signal resonated at $7.68 \mathrm{ppm}$ in 2 , while in case of the complexes the proton was detected at 8.51, 8.37, 8.26, and $8.20 \mathrm{ppm}$ for 3-6, respectively. The diastereotopic protons of the $\mathrm{NH}_{2}$ group coordinated to the metal centers were observed as wellseparated multiplets at 6.41 and $3.16 \mathrm{ppm}$ for 3 , at 7.19 and $4.12 \mathrm{ppm}$ for 4 , at 4.55 and $3.46 \mathrm{ppm}$ for 5 , and at 5.44 and $4.20 \mathrm{ppm}$ for 6 .

It might be expected that a mixture of diastereoisomers would be formed in the complexation reactions of ligands $(R)$ and $(S)-2$; however, only one main set of peaks for each complex $\mathbf{3} \mathbf{a}-\mathbf{6 b}$ was detected by NMR spectroscopy together with small amounts of a second species, possibly due to ligand exchange in solution. The configuration of the products in $\mathrm{CDCl}_{3}$ or $\mathrm{CD}_{2} \mathrm{Cl}_{2}$ solutions was determined by $2 \mathrm{D} \mathrm{NOE}$ experiments. For $\mathrm{Rh}$ and $\mathrm{Ir}$ complexes $\mathbf{5 a}-\mathbf{6 b}$, key NOE contacts between $\mathrm{Cp} *$ protons and $\mathrm{H}-8, \mathrm{NH}_{2}$, and $\mathrm{CH}_{3}$ protons of the aminoisobutyl chain were detected, while for $\mathrm{Ru}$ and $\mathrm{Os}$ complexes, contacts between cym aromatic protons and $\mathrm{H}-8$ and between aminoisobutyl chain and phenyl, amine, and $\mathrm{CH}_{2}$-benzyl protons were found (Figure 1 for $\mathbf{3 b}$ and $\mathbf{5 a}$ ).

To investigate whether the complexes exist in solution as a mixture of diastereoisomers, we recorded NMR spectra at a low temperature in $\mathrm{CD}_{2} \mathrm{Cl}_{2}$. As shown in Figure 2 for $\mathrm{Rh}$ complex $\mathbf{5 b}$, decreasing the temperature to $253 \mathrm{~K}$ results in the coalescence of some peaks, e.g., those assigned to the $\mathrm{PhCH}_{2}$

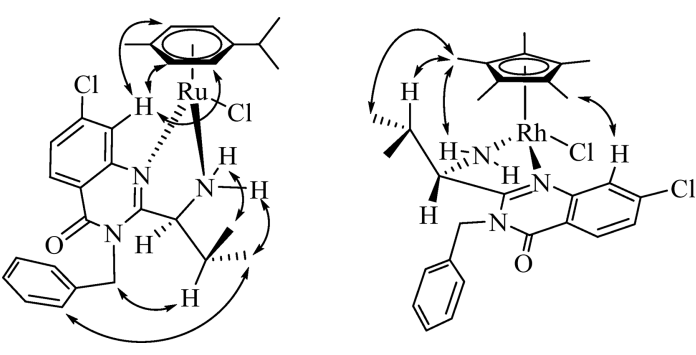

Figure 1. Stereochemistry of complexes $\mathbf{3 b}$ (left) and $\mathbf{5 a}$ (right) in solution. Double arrows indicate key NOE contacts.

and ${ }^{\mathrm{i}} \mathrm{Pr}$ groups. Lowering the temperature further to 203$213 \mathrm{~K}$ results in the formation of well-separated peaks due to the low exchange rate. The process was found to be reversible, and the spectra recorded at RT were identical to the initially recorded ones. Similar behavior was observed for the other complexes (Figures S1-S3).

Single crystals suitable for X-ray diffraction analysis were obtained by slow diffusion of $n$-hexane into solutions of the $\mathrm{Ru}$ and Os complexes in DCM, while in the case of the Rh and Ir complexes, crystals were grown by slowly cooling saturated methanolic solutions, which were stored at $-30^{\circ} \mathrm{C}$ for $48 \mathrm{~h}$. The $\mathrm{Ru}$ and $\mathrm{Os}$ complexes $\mathbf{3 b}$ and $\mathbf{4 a}$ bearing the $(S)-\mathbf{2}$ and (R)-2 ligands, respectively, crystallized in the $P 2_{1} 2_{1} 2_{1}$ and $P 2_{1}$ space groups. Compounds $5 \mathbf{a}$ and $\mathbf{6 a}$ and compounds $\mathbf{5 b}$ and 6b crystallized in the enantiomorphic pairs of $P 6_{1}$ (a) and $P 6_{5}$ (b) space groups, respectively. The latter compounds are isostructural and form analogous crystal lattices in the solid state.

All of these compounds displayed pseudo-octahedral geometry at the metal center with the piano-stool configuration. As expected, ligands $(R)-2$ and $(S)-2$ acted as $N, N$ chelators, forming five-membered rings with the metal ions by coordination through the $\mathrm{NH}_{2}$ nitrogen and $\mathrm{N}-1$ of the quinazoline moiety (Figures 3 and S4). In all cases, single diastereomers were isolated with the cym complexes $\mathbf{3 b}$ and $\mathbf{4 a}$ showing $R_{\mathrm{Ru}} S$ and $S_{\mathrm{Os}}, R$ configurations, while in case of the Cp* compounds $5 \mathrm{a}, 5 \mathrm{~b}, \mathbf{6 a}$, and $\mathbf{6 b}$, they were found to be $R_{\mathrm{M}}, R$ or $S_{\mathrm{M}}, S$. In the cym complexes, the arene ligand is in anticonfiguration to the isopropyl group of the quinazoline ligand and syn to the benzyl group of the quinazoline ligand, while it is vice versa for the $\mathrm{Rh}$ and Ir complexes with the Cp* ligands. In neither of the structures were H-bonding or $\pi$ stacking observed. The bond lengths around the metal center were for all complexes in similar ranges (Table 1 ). The $\mathrm{Rh}$ derivatives had slightly larger bond lengths from the Rh center 


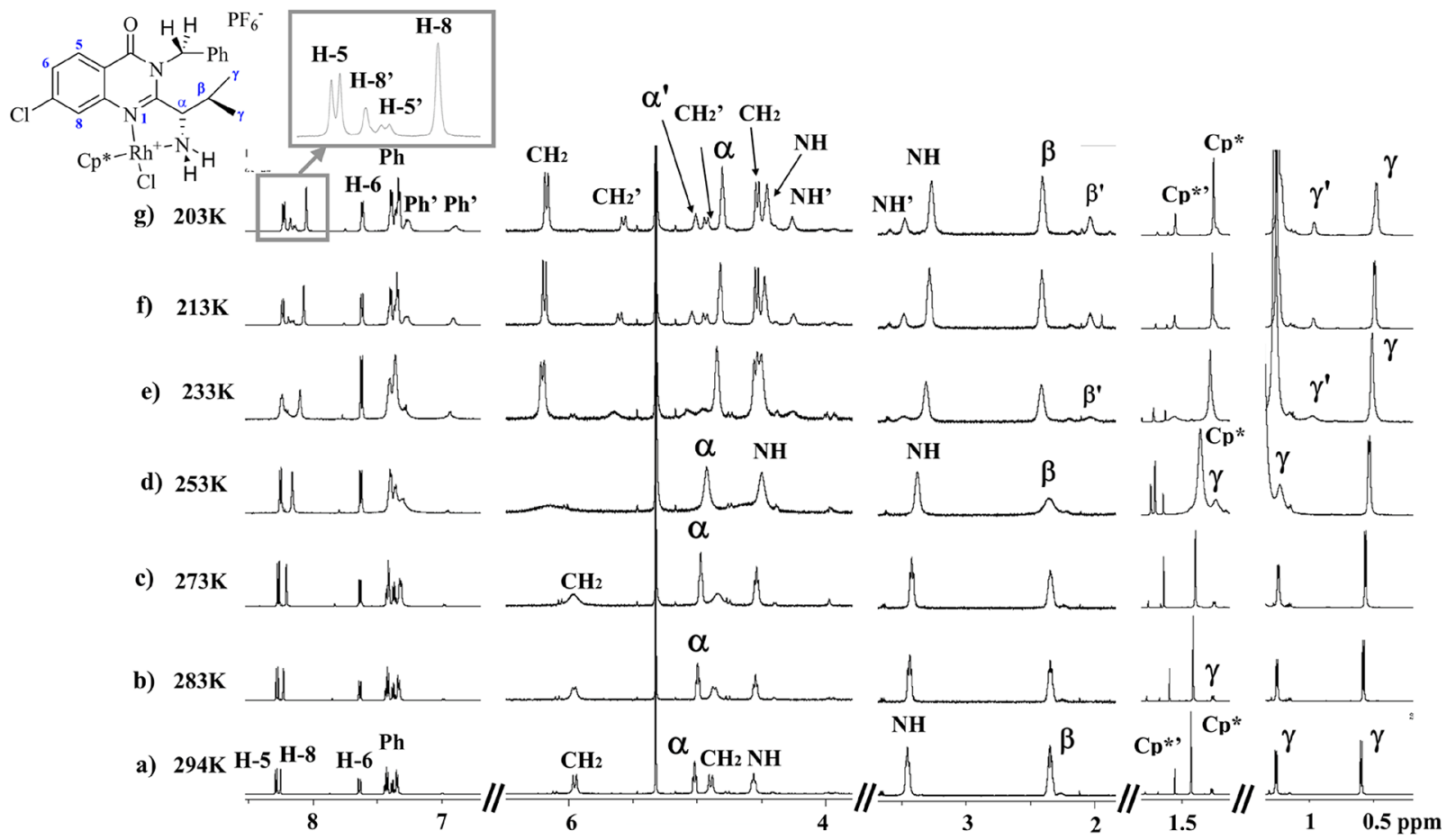

Figure 2. VT- ${ }^{1} \mathrm{H}$ NMR spectra of $\mathbf{5 b}$ in $\mathrm{CD}_{2} \mathrm{Cl}_{2}$.

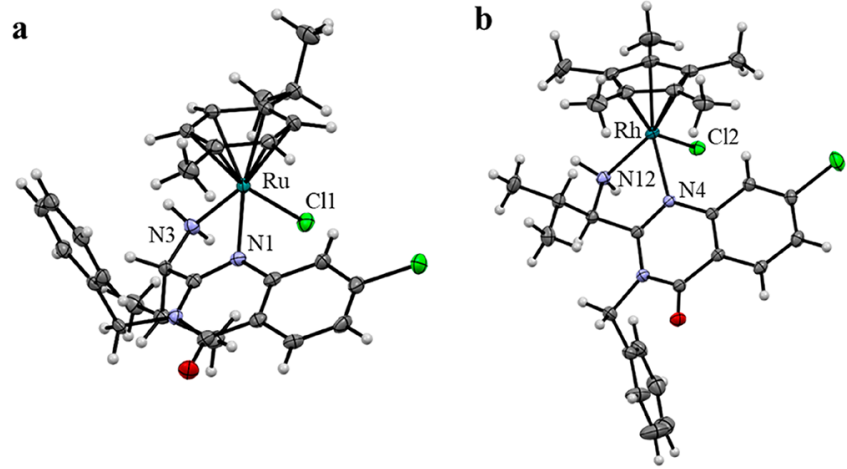

Figure 3. ORTEP representation of the molecular structures of (a) $\mathbf{3 b}$ and (b) 5a. Atomic displacement parameters are drawn at the 50\% probability level. Hydrogen atoms are represented as fixed-size spheres and unlabeled for clarity. Counteranions and cocrystallized solvent have been removed for clarity.

to the endocyclic nitrogen atom than found for Ir and especially $\mathrm{Ru}$ and $\mathrm{Os}$.

Table 1. Selected Bond Lengths (A) Found for the Molecular Structures of Complexes $3 b, 4 a, 5 a, 5 b, 6 a$, and $6 \mathrm{~b}$ about the Respective Metal Center

\begin{tabular}{|c|c|c|c|}
\hline \multirow[b]{2}{*}{ compound } & \multicolumn{3}{|c|}{ bond lengths/Å } \\
\hline & $\mathrm{M}-\mathrm{Cl}$ & $\mathrm{M}-\mathrm{N}_{\text {endo }}$ & $\mathrm{M}-\mathrm{NH}_{2}$ \\
\hline $3 b$ & $2.3967(12)$ & $2.137(4)$ & $2.104(4)$ \\
\hline $4 a^{a}$ & $2.391(2)$ & $2.137(6)$ & $2.124(7)$ \\
\hline $5 a$ & $2.3962(4)$ & $2.1586(12)$ & $2.1323(14)$ \\
\hline $5 \mathbf{b}$ & $2.3949(5)$ & $2.1593(17)$ & $2.1288(18)$ \\
\hline $6 a$ & $2.3943(9)$ & $2.148(3)$ & $2.130(3)$ \\
\hline $6 b$ & $2.3956(8)$ & $2.149(3)$ & $2.131(3)$ \\
\hline
\end{tabular}

${ }^{a}$ For one of the independent molecules in the unit cell.
In order to explore the foundation for the formation of crystals from different diastereomers dependent on the $\pi$ bound ligand at the metal center, density functional theory (DFT) calculations were conducted with Gaussian 09W. Calculation of the energetic differences in the ground state between the $\mathrm{Ru}$ and $\mathrm{Rh}$ complexes (3a, 3b, 5a, and $\mathbf{5 b}$, Table S2) and dependent on the enantiomer of ligand 2 revealed that the energies were very similar for the stereoisomers of the different metal centers ( $\mathrm{Ru}, \sim 0.3 \mathrm{kcal} / \mathrm{mol}$; Rh, $\sim 0.4 \mathrm{kcal} /$ $\mathrm{mol})$. This suggests that the stereochemistry does not determine a preferential formation of one or the other stereoisomer. It is more likely that the isolation of pure diastereomers is a result of the more facile crystallization of one of them.

NMR spectroscopic investigations in different solvents showed that the prepared complexes have differing stability in solution. In contrast to the $\mathrm{Rh}$ and $\mathrm{Ir}$ derivatives, the $\mathrm{Ru}$ and Os complexes are stable in aprotic solvents such as $\mathrm{CDCl}_{3}$ or $\mathrm{CD}_{2} \mathrm{Cl}_{2}$. The ${ }^{1} \mathrm{H}$ and ${ }^{13} \mathrm{C}\left\{{ }^{1} \mathrm{H}\right\}$ NMR spectra of the $\mathrm{Ru}$ and $\mathrm{Os}$ complexes showed one set of signals, while in the case of $\mathrm{Rh}$ and Ir compounds, additional sets of signals were present immediately after dissolving of the samples in $\mathrm{CD}_{2} \mathrm{Cl}_{2}$ (Figures S22-S37), with the large majority of the dissolved complexes remaining intact ( $>95 \%$ for $\mathrm{Rh}$ and $>85 \%$ for $\mathrm{Ir}$ ).

Metal-chlorido ligand bonds are often labile, and ligand exchange can occur in $\mathrm{H}_{2} \mathrm{O}$, methanol, or DMSO solutions. $^{49-51}$ Since usually the test compounds are dissolved in DMSO for biological studies, we investigated the stability of such solutions by ${ }^{1} \mathrm{H}$ NMR and UV-vis spectroscopy, as well as ESI-mass spectrometry. The ${ }^{1} \mathrm{H}$ NMR spectra showed that all complexes undergo changes in DMSO- $d_{6}$ solutions, resulting in the formation of a new set of signals (Figures S5-S8); however, the resulting solutions were stable in the dark for days. We observed differing kinetics in the chloride/ solvent exchange of the studied complexes for the $\mathrm{Ru} / \mathrm{Os}$ and $\mathrm{Rh} / \mathrm{Ir}$ couples. The $\mathrm{Rh}$ complexes undergo an extremely fast 
and almost complete chlorido/solvent ligand exchange which results in the appearance of only one main set of signals in fresh solution. The other complexes reacted significantly slower in the order of $\mathrm{Os}<\mathrm{Ru}, \mathrm{Ir}<\mathrm{Rh}$. The ESI-mass spectra (Figures S9-S12) and UV-vis spectra (Figure S14) confirmed that the complexes are sufficiently stable in DMSO solution in the dark, and only minor changes in the UV-vis spectra were observed, which may be assigned to chlorido/ DMSO ligand exchange.

In methanol solution, the $\mathrm{Ir}$ and $\mathrm{Ru}$ complexes underwent very fast cleavage of the $\mathrm{M}-\mathrm{Cl}$ bonds (ca. $31 \%$ ), occurring just after preparation of the solution, while their Os and especially $\mathrm{Rh}$ counterparts were more resistant toward such reactions with $22 \%$ of the Os and $12 \%$ of the Rh complex undergoing chlorido ligand exchange. This process can be suppressed by the addition of lithium chloride (as saturated solution in $\mathrm{CD}_{3} \mathrm{OD}$ ) and in the presence of a high concentration of chloride ions; this reaction is almost completely reversible (for $\mathbf{6 b}$ see Figure 4 and Figure S13).

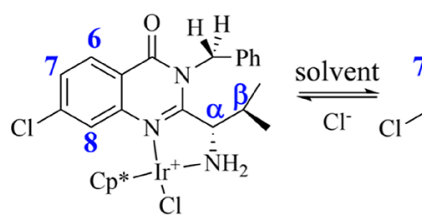

6b

f)

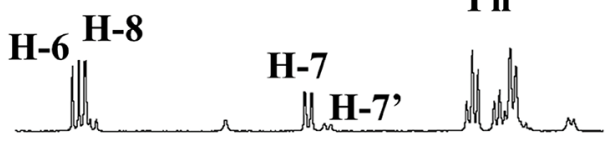

e)

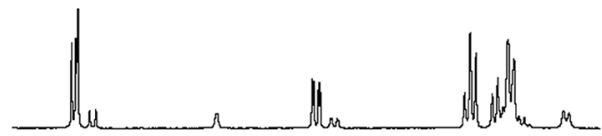

d)

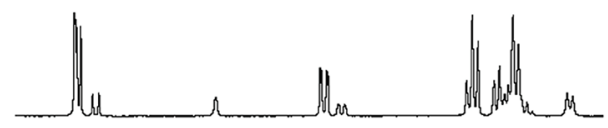

c)

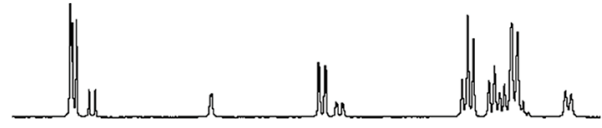

b)

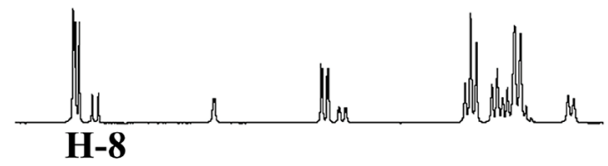

a)

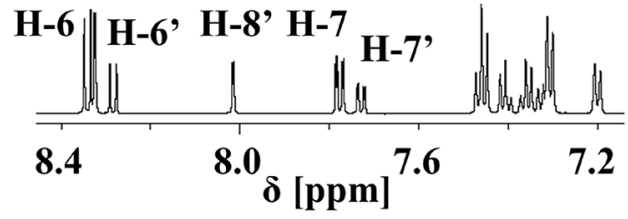

Figure 4. ${ }^{1} \mathrm{H}$ NMR spectra (aromatic region) of $\mathbf{6 b}$ in methanol- $d_{4}$ in the presence of various amounts of lithium chloride: (a) solution of $\mathbf{6 b}$ in $\mathrm{CD}_{3} \mathrm{OD},(\mathrm{b}) \mathbf{6} \mathbf{b}+20 \mu \mathrm{L}$ of $\mathrm{LiCl}$, (c) $\mathbf{6 b}+20 \mu \mathrm{L}$ of $\mathrm{LiCl}$ after $24 \mathrm{~h},(\mathrm{~d}) \mathbf{6 b}+40 \mu \mathrm{L}$ of LiCl, (e) $6 \mathbf{b}+90 \mu \mathrm{L}$ of LiCl, and (f) $6 \mathbf{b}+$ $190 \mu \mathrm{L}$ of $\mathrm{LiCl}$.
Dulbecco's Modified Eagle's Medium (DMEM) consists of numerous organic compounds which may act as ligands for organometallics. Therefore, we studied the solution behavior of the synthesized compounds in DMEM using UV-vis spectroscopy, mimicking cell culture conditions by adding the DMSO solutions of the complexes $(100 \mu \mathrm{M})$ while keeping the DMSO concentration as low as $0.5 \%$. The UV-vis spectra indicated that all compounds reacted within minutes with DMEM components (Figures S15-S18 and Table S3). On the basis of the DMEM composition and previously reported data for Ru complexes, ${ }^{52-54}$ we selected L-cystine (CysCys) and Lhistidine (His) for further studies. Both substances are prominent components of DMEM $(0.2 \mathrm{mM})$. UV-vis spectra and LC-MS analysis of freshly prepared solutions of the organometallic complexes $(100 \mu \mathrm{M})$ and the amino acids $(200 \mu \mathrm{M})$ revealed that the Ir and $\mathrm{Rh}$ complexes afforded a mixture of organometallic species when incubated with His. The UV-vis spectra of mixtures of $\mathbf{5 a}$ and $\mathbf{6 a}$ with His showed the quick formation of new species (for 5a see Figure S19, for 6a see Figure S20), as was observed for incubation mixtures of 5a and 6a in DMEM (Figures S17 and S18, respectively). The LC-MS data collected for a freshly prepared mixture of Ir complex 6a with His (Figure S21) showed singly charged ions at a retention time of $0.17 \mathrm{~min}$. These ions were detected at $\mathrm{m} /$ $z 704.3,668.3$, and 482.2 and assigned to $\left[\mathrm{M}-\mathrm{PF}_{6}\right]^{+},[\mathrm{M}-$ $\left.\mathrm{HCl}-\mathrm{PF}_{6}\right]^{+}$, and the His adduct $\left[\left(\mathrm{Cp}^{*}\right) \operatorname{Ir}(\mathrm{His})-\mathrm{H}\right]^{+}$, respectively. After $30 \mathrm{~min}$ of stirring at $\mathrm{RT}$, two main peaks were present in the chromatogram. The mass spectrum collected at $0.17 \mathrm{~min}$ featured the same $\mathrm{m} / \mathrm{z}$ values as before with the His adduct at $m / z 482.2$ being the base peak (Figure S22). A second species eluted at 0.26 min yielded ions at $\mathrm{m} / z$ 342.2 assigned to $[(R)-2+\mathrm{H}]^{+}$. Similar results were obtained for the $\mathrm{Rh}$ complex $5 \mathrm{a}$. A peak eluting at $0.17 \mathrm{~min}$ gave ions at $\mathrm{m} / z 614.3,578.3$, and 392.2 , which corresponded to $[\mathrm{M}-$ $\left.\mathrm{PF}_{6}\right]^{+}$and $\left[\mathrm{M}-\mathrm{HCl}-\mathrm{PF}_{6}\right]^{+}$and $[(\mathrm{Cp} *) \mathrm{Rh}(\mathrm{His})-\mathrm{H}]^{+}$ (Figure S23), followed by a second compound eluting at 0.26 min with ions assigned to $[(R)-2+\mathrm{H}]^{+}$. After $30 \mathrm{~min}$ of stirring of 6a with His, only singly charged ions at $m / z 392.2$ and 342.2 stemming from the His adduct $\left[\left(\mathrm{Cp}^{*}\right) \mathrm{Rh}(\mathrm{His})-\right.$ $\mathrm{H}]^{+}$and protonated ligand $[(R)-2+\mathrm{H}]^{+}$were observed (Figure S24). Only the $\mathrm{Rh}$ complex reacted with cystine and released (R)-2, as detected by MS at $m / z 342.2$ for $[(R)-2+\mathrm{H}]^{+}$, whereas all other complexes remained unchanged. Interestingly, neither the $\mathrm{Ru}$ nor the Os derivatives were found to form stable complexes with $\mathrm{His}$ or cystine during the $30 \mathrm{~min}$ incubation period, and only $\left[\mathrm{M}-\mathrm{PF}_{6}\right]^{+}$and $[\mathrm{M}-\mathrm{HCl}-$ $\left.\mathrm{PF}_{6}\right]^{+}$ions were detected.

Antiproliferative Activity. A high level of inhibition of KSP activity may result in significant antiproliferative effects in cancer cells. ${ }^{55,56}$ Therefore, the cytotoxicity of $(R)-2$ and $(S)-2$ and their organometallic complexes $3 a-6 a$ and $3 b-6 b$ toward human colorectal carcinoma (HCT116), hepatocellular carcinoma (HepG2), large cell lung cancer (NCI-H460), colorectal adenocarcinoma (SW480 and SW620), and cervical squamous cell carcinoma ( $\mathrm{SiHa}$ ) cells was studied (Table 2 ). The cell lines used exhibited variable sensitivity to the parental compounds, $(R)$-ispinesib and $(S)$-ispinesib $((R)$ - and $(S)-\mathbf{1}$, respectively). (R)-1 exhibited high cytotoxicity toward the majority of cells studied with $\mathrm{IC}_{50}$ values $<8 \mathrm{nM}$ for most of the studied cancer cell lines with the exception for HepG2, for which the $\mathrm{IC}_{50}$ value was $0.53 \pm 0.01 \mu \mathrm{M}$. The corresponding $(S)$-enantiomer $(S)$-1 was characterized by significantly lower cytotoxicity with $\mathrm{IC}_{50}$ values in the high nanomolar or even 
Table 2. In Vitro Antiproliferative Activity of $(R)$ - and (S)-Ispinesib, $(R)-2$ and $(S)-2$ and Their Organometallic Complexes $3 a-6 a$ and $3 b-6 b$, Respectively, in Human Cancer Cell Lines (Exposure Time 72 h; Mean IC I0 $\left._{\text {Values }} \pm S^{2}, n=3\right)^{a}$

\begin{tabular}{|c|c|c|c|c|c|c|}
\hline \multirow[b]{2}{*}{ compound } & \multicolumn{6}{|c|}{$\mathrm{IC}_{50}[\mu \mathrm{M}]$} \\
\hline & HepG2 & SW620 & НCT116 & NCI-H460 & SW480 & $\mathrm{SiHa}$ \\
\hline (R)-1 & $0.53 \pm 0.01$ & $<0.008$ & $<0.008$ & $<0.008$ & $<0.008$ & $<0.008$ \\
\hline$(S)-\mathbf{1}$ & $2.8 \pm 0.4$ & $2.5 \pm 0.9$ & $0.08 \pm 0.04$ & $0.20 \pm 0.07$ & $0.86 \pm 0.38$ & $0.81 \pm 0.27$ \\
\hline (R)-2 & $74 \pm 33^{*}$ & $9.0 \pm 3.6$ & $0.28 \pm 0.19$ & $1.2 \pm 0.1$ & $3.8 \pm 0.4$ & $4.7 \pm 0.6$ \\
\hline$(S)-\mathbf{2}$ & $175 \pm 108^{*}$ & $\gg 30$ & $20 \pm 3$ & $36 \pm 3$ & $46 \pm 3$ & $31 \pm 2$ \\
\hline $3 a$ & $63 \pm 36^{*}$ & $1.4 \pm 0.3$ & $0.55 \pm 0.04$ & $1.6 \pm 0.3$ & $4.0 \pm 0.6$ & $5.1 \pm 0.3$ \\
\hline $3 b$ & $12 \pm 3$ & $0.94 \pm 0.20$ & $3.6 \pm 0.1$ & $6.9 \pm 0.1$ & $13 \pm 1$ & $14 \pm 1$ \\
\hline $4 a$ & $72 \pm 23^{*}$ & $2.0 \pm 0.4$ & $0.66 \pm 0.07$ & $2.0 \pm 0.2$ & $3.8 \pm 0.1$ & $5.5 \pm 0.6$ \\
\hline $4 b$ & $45 \pm 17^{*}$ & $0.67 \pm 0.01$ & $2.3 \pm 0.2$ & $5.4 \pm 0.2$ & $7.5 \pm 1.2$ & $11 \pm 1$ \\
\hline $5 a$ & $47 \pm 15^{*}$ & $1.0 \pm 0.2$ & $0.29 \pm 0.03$ & $1.2 \pm 0.1$ & $3.7 \pm 0.3$ & $4.4 \pm 0.04$ \\
\hline $5 b$ & $53 \pm 11^{*}$ & $84 \pm 33^{*}$ & $18 \pm 1$ & $32 \pm 1$ & $40 \pm 1$ & $27 \pm 1$ \\
\hline $6 a$ & $11 \pm 2$ & 0.86 (too wide) & $0.41 \pm 0.05$ & $0.91 \pm 0.01$ & $2.9 \pm 0.3$ & $3.1 \pm 0.2$ \\
\hline $6 b$ & $110 \pm 77^{*}$ & $39 *($ too wide $)$ & $14 \pm 2$ & $29 \pm 3$ & $40 \pm 2$ & $26 \pm 1$ \\
\hline
\end{tabular}

$a_{(*)}$ Over range; (too wide), the curve drops down rapidly so no SD can be calculated.
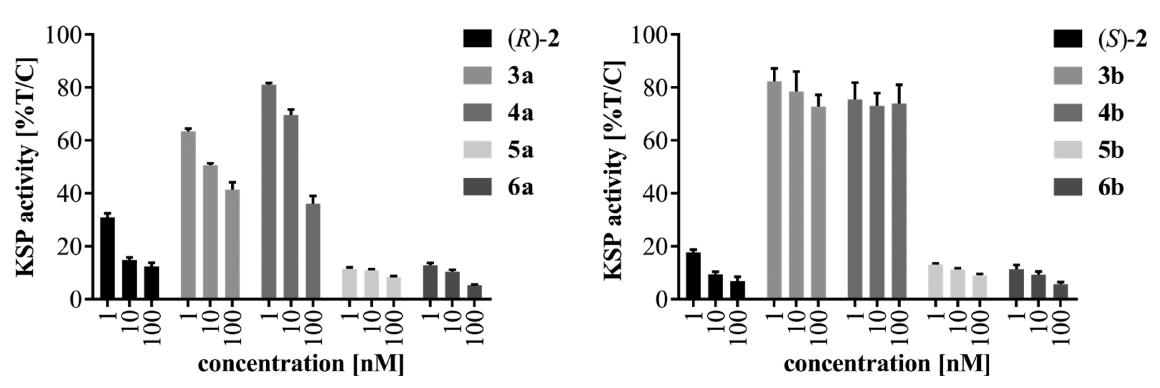

Figure 5. KSP activity in the presence of increasing concentrations of the ligands $(R)-\mathbf{2}$ and $(S)-\mathbf{2}$ and of their organometallic complexes $3 \mathbf{a}-\mathbf{6 a}$ and $3 \mathbf{b}-\mathbf{6 b}$. Data are presented as mean \pm SEM, $n=3$ or 4 (for controls).

micromolar range. In comparison to the enantiomers of $\mathbf{1}$, the ligands $(R)$ - and $(S)-2$ were much less cytotoxic than the analogous parent compounds. Metal complexation resulted in augmented biological activity of the investigated compounds, in both the $(R)$ - and $(S)$-series. However, metal complexes of the $(R)$-ligands were generally much more active than their $(S)$ counterparts. The overall antiproliferative properties of the investigated compounds in the selected cell line panel can be ranked in the following order: $(R)-\mathbf{1}>(S)-\mathbf{1}>\mathbf{6 a}>\mathbf{3 a} \approx \mathbf{4} \mathbf{a} \approx$ $\mathbf{5 a}>(R)-\mathbf{2}>\mathbf{3 b}>\mathbf{4 b}>\mathbf{6} \mathbf{b}>\mathbf{5 b}>(S)-\mathbf{2}$. Metal complexation did not significantly alter the activity of $(R)-2$ derivatives in the cell lines tested, except for moderately elevated effects of the Ir complex 6a. In contrast, although the antiproliferative potential of $(S)-2$ is significantly lower than that of $(R)-2$, metal complexation elevated its activity. The $\mathrm{Ru}$ and Os complexes $\mathbf{3 b}$ and $\mathbf{4 b}$ of (S)-2 exerted potent biological effects demonstrating between 2 -fold ( $\mathbf{3 b}$ in $\mathrm{SiHa}$ cells) and 9-fold (4b in HCT116) higher activity than the parent organic ligand, showing a clear impact of metal coordination.

Considering the individual cell line vulnerability, HCT116 proved to be the most sensitive cell line to the compounds investigated, including ispinesib. Additionally, all the complexes of (R)-2 were similarly potent in this cell line as the ligand itself.

KSP Inhibition. Ispinesib is a well established KSP inhibitor with $\mathrm{IC}_{50}$ values reported to be in the range of $0.5-4.6 \mathrm{nM}^{57}$ The ability of the synthesized compounds to inhibit KSP activity was studied by the ATP hydrolysis assay. We found that the $\mathrm{Rh} / \mathrm{Ir}$ complexes $\mathbf{5 a}, \mathbf{5 b}, \mathbf{6 a}$, and $\mathbf{6 b}$ exhibited higher activity in comparison to the ispinesib-derived ligands $(R)-2$ and $(S)-2$ (Figure 5), even at concentrations as low as $1 \mathrm{nM}$. In contrast, the $\mathrm{Ru}$ and $\mathrm{Os}$ complexes are significantly less active. Comparison of the $\mathrm{Rh}$ and $\mathrm{Ir}$ complexes bearing the $(S)-2$ or $(R)-2$ ligands revealed that the observed KSP inhibitory activity is virtually independent of their conformation. In contrast, the $\mathrm{Ru}$ and $\mathrm{Os}(R)$-2-type complexes were found to be significantly stronger KSP inhibitors than analogous $(S)-2$ complexes, with the former leading to a maximal inhibition of approximately $40 \%$ at $100 \mathrm{nM}$ concentration. These results are especially interesting in view of the fact that ruthenium complexes of another KSP inhibitor, monastrol, were shown to exhibit lower KSP inhibitory activity than the parent compound. ${ }^{58,59}$

Docking Study. In order to elucidate contrasting structural features of relevance to protein interaction for the organometallic compounds, molecular modeling was used to investigate the possible binding mode for the ligands $(R)$ and $(S)-\mathbf{2}$ and their half-sandwich complexes $\mathbf{3} \mathbf{a}-\mathbf{6} \mathbf{b}$ as well as the respective diastereomers $\mathbf{3} \mathbf{a}^{\prime}, \mathbf{3} \mathbf{b}^{\prime}, \mathbf{5} \mathbf{a}^{\prime}$, and $\mathbf{5} \mathbf{b}^{\prime}$ to KSP. While the complexes may undergo ligand exchange in aqueous solution to form aqua complexes, or in the presence of proteins to form covalent bonds, for the reason of comparability, we decided to dock the chlorido complexes. The KSP cocrystal structure with ispinesib derived from Homo sapiens was obtained from the Protein Data Bank (PDB ID: 4AP0; resolution $2.59 \AA) .^{60}$ Co-crystallized ispinesib was removed and redocked to the allosteric site with excellent docking overlay (RMSD $=0.356 \AA$ for GoldScore; Table S4 and Figure $\mathrm{S} 25 \mathrm{~A}$ ). Ispinesib is buried in the allosteric site and displays numerous interactions with residues of the inhibitor-binding pocket. $^{61}$ Both the cocrystallized ligand and its redocked configuration showed that the benzyl moiety of the ligand is 
buried deeply in the hydrophobic part of the pocket, where it stacks with the Pro137 ring and makes an edge-to-face interaction with the side chain of Trp127. Moreover, it is found to be in lipophilic contact with the side chains of Tyr211, Ala218, Ala133, Glu118, Arg119, Leu160, and Leu214 (Figure S25B). The similarities in the docked configurations to the one described in the literature ${ }^{23,61-63}$ and a low RMSD value suggest the reliability and reproducibility of the docking protocol.

The spatial orientations and interactions (Tables 3 and S5) found for $(R)$ - and $(S)-2$ and their half-sandwich complexes

Table 3. GoldScores for the Docking Scores of $(R)$ - and $(S)$ 2 and Their Half-Sandwich Complexes $3 a-6 b$ As Well As the Respective Diastereomers $3 a^{\prime}, 3 b^{\prime}, 5 a^{\prime}$, and $5 b^{\prime}$, Dependent on the Chiral Configuration at the Metal Center and Ligand

\begin{tabular}{|ccccc|}
\hline \multicolumn{5}{c}{ GoldScore } \\
compounds & $(\boldsymbol{R})$ & \multicolumn{4}{c|}{$(\boldsymbol{S})$} \\
\hline $\mathbf{2}$ & 61.5 & 58.8 & $\left(S_{\mathrm{M}}, S\right)$ \\
\hline configuration & $\left(S_{\mathrm{M}}, R\right)$ & $\left(R_{\mathrm{M}}, S\right)$ & $\left(R_{\mathrm{M}}, R\right)$ & $\mathbf{b}$ \\
\hline compound & $\mathbf{a}$ & $\mathbf{b}$ & $\mathbf{a}$ & \\
\hline $\mathbf{3}$ & 78.8 & 59.1 & & 59.1 \\
$\mathbf{4}$ & 78.9 & 52.7 & & 56.3 \\
$\mathbf{5}$ & & & 59.6 & 51.6 \\
$\mathbf{6}$ & & & 60.0 & \\
$\mathbf{3}^{\prime}$ & & & 54.4 & \\
$\mathbf{5}^{\prime}$ & 49.0 & 50.4 & & \\
\hline
\end{tabular}
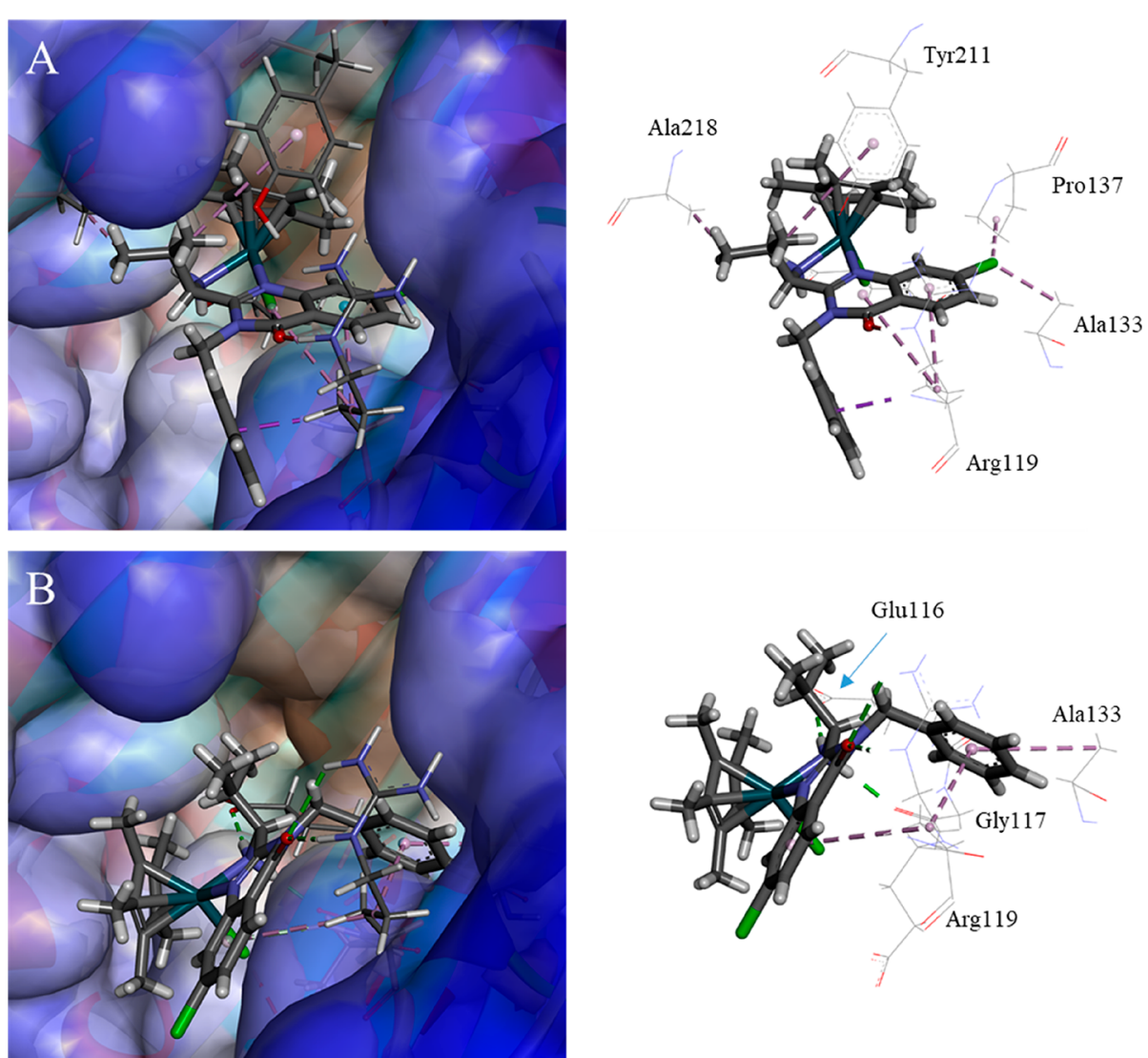

$3 \mathbf{a}-\mathbf{6} \mathbf{b}$ as well as the respective diastereomers $3 \mathbf{a}^{\prime}, \mathbf{3} \mathbf{b}^{\prime}, \mathbf{5} \mathbf{a}^{\prime}$, and $\mathbf{5} \mathbf{b}^{\prime}$ show that the compounds may bind to the same site as previously reported, ${ }^{60-64}$ which is suggestive to be related to their anticancer activity. Both $(R)$ - and $(S)-2$ show similar interactions with the protein with the main difference being a hydrogen bond of the latter to Tyr211 and a slightly higher GoldScore for the $(R)$ enantiomer.

For the organometallic compounds, in general, the $S_{\mathrm{M}}, R$ and $R_{\mathrm{M}}, R$ isomers showed higher predicted scores than the isomers derived from $(S)-2$ with the exception of the $\mathrm{Rh}$ complex pair $\mathbf{5} \mathbf{a}^{\prime} / \mathbf{5} \mathbf{b}^{\prime}$ (Table 3). While the isostructural compounds $\mathbf{3 a}$ and 4a are found in virtually identical positions in the structure, their diastereomers $\mathbf{3 b}$ and $\mathbf{4 b}$ behaved very differently, with the Os complex giving a lower docking score than the $\mathrm{Ru}$ analogue and interaction with a limited number of amino acids (Table S5). However, these differences have a big impact on the cytotoxic activity and the KSP inhibition with $(R)-2$ based $\mathbf{3 a}$ and $\mathbf{4 a}$ being more potent than $\mathbf{3 b}$ and $\mathbf{4 b}$ in both assays. Surprisingly, the observations were very different for the $\mathrm{Rh}$ and $\mathrm{Ir}$ complexes. While the isomers $\mathbf{5 a} / \mathbf{5 b}$ and $\mathbf{6 a} / \mathbf{6 b}$ follow a similar pattern in the cytotoxicity assay, they are equally potent in inhibiting KSP independent of the configuration of the ligand or the metal center. This trend is also reflected in the GoldScores found for these compounds, which are very similar but significantly lower than those found for the $\mathrm{Ru}$ and $\mathrm{Os}$ complexes of $(R)-2$. This suggests that for the latter classes of compounds KSP may not be the target, but their cytotoxic potential is exhibited through other means.

The docked configurations of $\mathbf{R h}$ complexes $\mathbf{5 a}$ and $\mathbf{5 b}$ into the binding site are shown in Figure 6. For 5a, the $\mathrm{Cp}^{*}$ moiety 


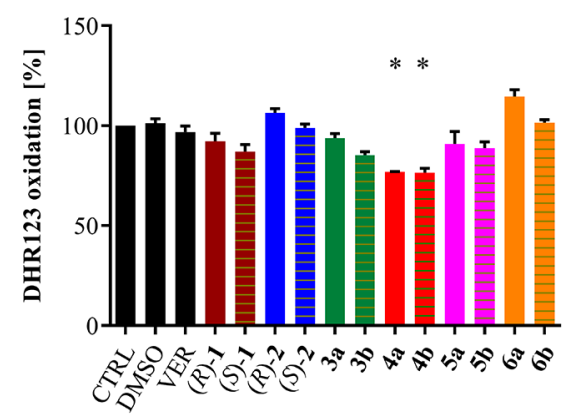

A

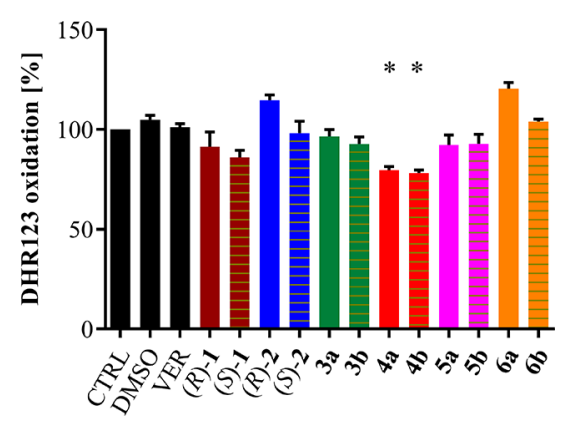

B

Figure 7. Ability to induce ROS generation in SW620 (left, A) and HepG2 (right, B) cells after 4-h exposure to complexes 3a-6b (1 $\mu \mathrm{M})$. CTRL (expressed as 100\%), cells in DMEM complete culture medium; DMSO, cells in DMEM complete culture medium with addition of DMSO (0.1\%) as a solvent control; VER, cells in DMEM complete culture medium with addition of $10 \mu \mathrm{M}$ verapamil to exclude potential impact of ABCB1 activity on the intracellular rhodamine 123 level. Results are expressed as mean \pm SEM, $n=3$. Asterisks denote statistical significance against respective solvent controls $(P<0.01$, one-way ANOVA followed by post hoc Tukey test).

is embedded deeply in the hydrophobic pocket formed by Leu214, Ala133, and Trp127 (Figure 6A). The quinazolinyl moiety interacts with parts of the side chain of Arg119, and the chlorine substituent of the quinazolinyl moiety sits in another mostly hydrophobic pocket formed by the side chain of Ala133 and Pro137. The benzyl moiety of the ligand is not inserted into the active site pocket and is more exposed to the aqueous phase, especially when compared to $3 a$ and $4 a$, which gave much higher docking scores in a similar range to ispinesib (Table S4). However, the isopropyl group is only partly buried and interacting with parts of the side chains of Tyr211 and Ala218 (Figure 6A). Upon docking of the $\mathbf{5 b}$ isomer, the ring systems are "flipped" relative to 5a (Figure 6B), and in this case the $\mathrm{Cp}^{*}$ ligand is more exposed to the aqueous phase. The carbonyl group of the quinazolinyl moiety exhibited hydrogen bonding with the side chain of Arg119. The benzyl group sits deep in the hydrophobic pocket and forms an edge-to-face stacking interaction with the side chains of Ala133 and Arg119. The isopropyl group is embedded deep and orientated toward the binding pocket of ispesinib.

In addition to the diastereomers characterized by X-ray diffraction analysis, we docked diastereomeric structures to $3 \mathbf{a}$, $\mathbf{3} \mathbf{b}, \mathbf{5} \mathbf{a}$, and $\mathbf{5 b}$, i.e., $\mathbf{3} \mathbf{a}^{\prime}, \mathbf{3} \mathbf{b}^{\prime}, \mathbf{5} \mathbf{a}^{\prime}$, and $\mathbf{5} \mathbf{b}^{\prime}$ (Tables 3 and S5), to investigate the impact of the $\pi$-bound ligand and of chirality on the docking behavior. Comparison of the GoldScores of isostructural $\mathbf{3 a} / \mathbf{4 a}$ and $\mathbf{5 a} \mathbf{a}^{\prime}$ shows that the $\mathrm{Ru}-$ and $\mathrm{Os}(\mathrm{cym})$ complexes resulted in much higher scores than their $\mathrm{Rh}\left(\mathrm{Cp}^{*}\right)$ counterpart. The effect was found to be less pronounced for the complexes featuring $(S)-2$, but the trend is the same. In both cases, the structures of the complexes were orientated very differently for the docking result, as they were when comparing $5 a / 6 a$ with $3 a^{\prime}$ and $5 b / 6 b$ with $3 b^{\prime}$.

Overall, there are significant differences in the docking results for the different isomers of the organometallics both in terms of orientation but also in terms of their interactions with the protein, which may have an impact on their modes of action. This is also supported by the biological data collected for the compound classes, under the limitations of docking as outlined above regarding the possibility of chlorido/aqua ligand exchange and/or coordination to donor atoms of the protein. The obtained results correlate with the experimental inhibitor activity of KSP only in discriminating of the stereochemistry of ligand $\mathbf{2}$ but do not correlate with distinguishing of the organometallic moieties.
ROS Generation. It is often postulated that organometallic complexes induce oxidative stress in cancer cells. ${ }^{31}$ Therefore, we studied the generation of reactive oxygen species (ROS) induced by complexes $\mathbf{3 a - 6 b}$ in SW620 and HepG2 cells, differing in sensitivity toward the investigated compounds, using the dihydrorhodamine 123 (DHR123) oxidation assay (Figure 7). Surprisingly, the overall pattern of DHR123 oxidation was similar between these two cell lines, indicating that the redox balance disturbance is independent of the antiproliferative potential of the compounds studied. It must be noted, however, that both osmium complexes consistently decreased the oxidation rate of DHR123 compared to the control. DHR123 is considered a nonspecific reactive oxygen/ nitrogen species indicator, and therefore these results suggest that either some intracellular source of ROS is inhibited by the investigated compounds or the compounds themselves exhibit some antioxidant activity. Such activity was demonstrated, for example, for $\mathrm{Ni}$ (II) quinazoline complexes and Mn-porphyrins, acting as low molecular weight superoxide dismutase mimics. $^{65,66}$

To test these hypotheses, we performed a robust ABTS [2,2'-azinobis(3-ethylbenzothiazoline-6-sulfonic acid)] radical cation reduction assay. ${ }^{67}$ We were able to demonstrate that both Os (4a and $\mathbf{4 b}$ ) and to a lesser extent also $\mathrm{Ru}$ (3a and $\mathbf{3 b}$ ) complexes exhibited antioxidant properties (Figure 8). It can be therefore inferred that the osmium complexes add to the antioxidant pool of the cell and thus reduce the DHR123 oxidation rate.

Cellular Accumulation. The antiproliferative potential of anticancer agents is, at least to some extent, dependent on their cellular accumulation. Therefore, we aimed to determine the amount of the respective metal accumulated in SW620 cancer cells by ICP-MS following exposure to the synthesized complexes. The choice of the cell line was dictated by the facts that (i) it responds well to ispinesib (Table 2) and (ii) it does not express any of the major multidrug resistance proteins that could alter the influx kinetics of the investigated compounds. ${ }^{68}$ However, this experimental approach based on the sole metal measurement does not allow for discrimination between the metal complex accumulated inside the cell or bound to the cell surface. In this case, there is no clear correlation between cytotoxic/cytostatic effects and the determined metal concentration. For all compounds, the amount of metal detected was highest after $1 \mathrm{~h}$ and declined over time (Figure 9). The Os complexes reached a significantly 


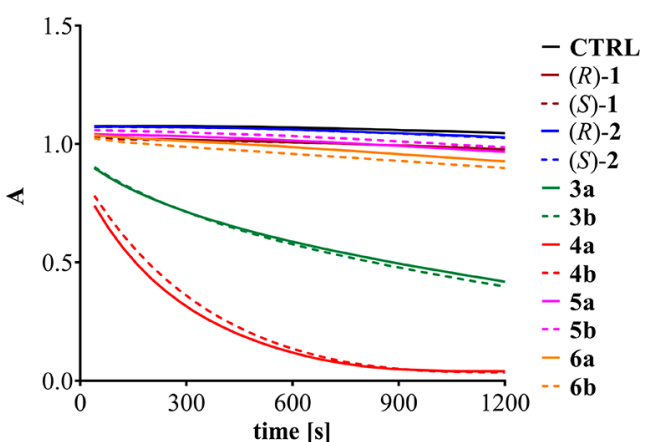

Figure 8. Total antioxidant capacity of the investigated compounds assayed by ABTS radical cation reduction. Data from a representative experiment performed in triplicate. Error bars were omitted to increase the legibility of the plot.

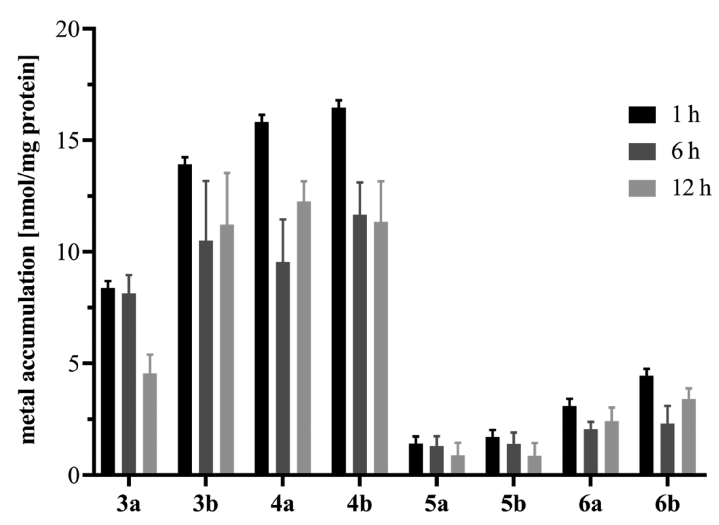

Figure 9. Accumulation of $3 \mathbf{a}-6 \mathbf{b}(10 \mu \mathrm{M})$ in SW620 cells treated for 1,6 , and $12 \mathrm{~h}$. Data are presented as means \pm SEM, $n=3$.

higher concentration than the corresponding $\mathrm{Ru}$ complexes

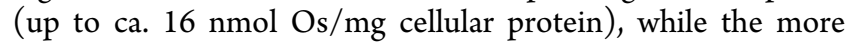
cytotoxic $\mathbf{5 b}$ and $\mathbf{6 b}$ complexes were detected in concentrations up to 1.4 and $3.4 \mathrm{nmol}$ of metal/mg protein, respectively. Interestingly, for complexes bearing $(S)-2$ as the ligand, slightly higher values were found compared to the more active derivatives of (R)-2. As mentioned before, Ir and, especially, Rh complexes tend to release $(R)$ - and $(S)-2$ when incubated with histidine and/or cystine, which presumably may also occur in a culture medium. Metal species may enter the cells by the ligand conveyor mechanism similar to that postulated for phosphine gold complexes in the case of auranofin $^{69}$ but may be then readily exported from the cytoplasm, presumably with glutathione, as was demonstrated for cisplatin. ${ }^{70}$ This would explain the observations in terms of detected low metal content in cell uptake studies, high antiproliferative activity, and excellent KSP inhibitory potency.

\section{CONCLUSIONS}

Two series of organoruthenium, -osmium, -rhodium, and -iridium complexes with the ligands $(R)$ - and $(S)$-2-(1-amino2-methylpropyl)-3-benzyl-7-chloroquinazolin-4(3H)-one were synthesized. The series differed in their antiproliferative potentials, with the complexes of the $(R)$-configured ligands exerting significantly stronger biological effects with $\mathrm{IC}_{50}$ values in the high nanomolar range for the most susceptible cell line tested as compared to low to medium micromolar activity for the corresponding $(S)$-analogues. Interestingly, the effect of the metal center on the antiproliferative potential of the investigated compounds was rather moderate. On the other hand, introduction of a metal center significantly affected the anti-/prooxidative properties, cellular accumulation, and inhibitory effects on KSP. The Os and Ru complexes inhibited ROS formation, avidly accumulated in cells, and exerted low to moderate effects on KSP activity. On the other hand, the Rh and Ir complexes were potent KSP inhibitors, despite the low stability of the $\mathrm{Rh}$ complexes which warrants further investigation. The level of their cellular accumulation/binding was an order of magnitude lower, and their effects on intracellular reactive oxygen species level were negligible. These observations may be at least partially explained by differences in the susceptibility of the metal complexes for ligand exchange reaction.

\section{ASSOCIATED CONTENT}

\section{Supporting Information}

The Supporting Information is available free of charge at https://pubs.acs.org/doi/10.1021/acs.inorgchem.0c00957.

Synthesis and characterization of complexes; general information on methods; characterization; copies of the UV-vis, MS, and NMR spectra; and additional figures (PDF)

\section{Accession Codes}

CCDC 1955610-1955613 and 1979283-1979284 contain the supplementary crystallographic data for this paper. These data can be obtained free of charge via www.ccdc.cam.ac.uk/ data_request/cif, or by emailing data_request@ccdc.cam.ac. uk, or by contacting The Cambridge Crystallographic Data Centre, 12 Union Road, Cambridge CB2 1EZ, UK; fax: +44 1223336033.

\section{AUTHOR INFORMATION}

\section{Corresponding Authors}

Damian Plażuk - Department of Organic Chemistry, Faculty of Chemistry, University of Łódź, 91-403 Łódź, Poland; ○ orcid.org/0000-0002-2898-6604; Email: damian.plazuk@ chemia.uni.lodz.pl

Christian G. Hartinger - School of Chemical Sciences, The University of Auckland, Auckland 1142, New Zealand; ○ orcid.org/0000-0001-9806-0893; Email: c.hartinger@ auckland.ac.nz

\section{Authors}

Michał Łomzik - Department of Organic Chemistry, Faculty of Chemistry, University of Łódź, 91-403 Łódź, Poland; (1) orcid.org/0000-0003-4847-3520

Muhammad Hanif - School of Chemical Sciences, The University of Auckland, Auckland 1142, New Zealand; (1) orcid.org/0000-0002-2256-2317

Aleksandra Budniok - Cytometry Lab, Department of Molecular Biophysics, Faculty of Biology and Environmental Protection, University of Łódź, 90-236 Łódź, Poland

Andrzej Błauz - Cytometry Lab, Department of Molecular Biophysics, Faculty of Biology and Environmental Protection, University of Łódź, 90-236 Łódź, Poland

Anna Makal - Faculty of Chemistry, Biological and Chemical Research Centre, University of Warsaw, 02-089 Warszawa, Poland; (1) orcid.org/0000-0001-9357-2670

Daniel M. Tchón - Faculty of Chemistry, Biological and Chemical Research Centre, University of Warsaw, 02-089 Warszawa, Poland 
Barbara Leśniewska - Faculty of Chemistry, University of Biatystok, 15-245 Biatystok, Poland

Kelvin K. H. Tong - School of Chemical Sciences, The University of Auckland, Auckland 1142, New Zealand

Sanam Movassaghi - School of Chemical Sciences, The University of Auckland, Auckland 1142, New Zealand

Tilo Söhnel - School of Chemical Sciences, The University of Auckland, Auckland 1142, New Zealand

Stephen M. F. Jamieson - Auckland Cancer Society Research Centre, The University of Auckland, Auckland 1142, New Zealand; (1) orcid.org/0000-0002-5485-9211

Ayesha Zafar - School of Chemical Sciences, The University of Auckland, Auckland 1142, New Zealand

Jóhannes Reynisson - School of Pharmacy and Bioengineering, Keele University, Staffordshire ST5 5BG, United Kingdom

Błażej Rychlik - Cytometry Lab, Department of Molecular Biophysics, Faculty of Biology and Environmental Protection, University of Łódź, 90-236 Łódź, Poland; 이이.org/00000001-8928-5900

Complete contact information is available at:

https://pubs.acs.org/10.1021/acs.inorgchem.0c00957

\section{Author Contributions}

The manuscript was written through contributions of all authors. All authors have given approval to the final version of the manuscript.

\section{Notes}

The authors declare no competing financial interest.

\section{ACKNOWLEDGMENTS}

This study was financially supported by the National Science Centre Poland (NCN) based on decision UMO-2015/17/B/ ST5/02331. We also thank the University of Auckland (University of Auckland Doctoral Scholarship to K.K.-H.T.), and the Health Research Council of New Zealand (Hercus Fellowship to M.H.) for funding. We are grateful to Tanya Groutso and Tony Chen for collecting the X-ray diffraction and MS data, respectively. We thank Mie Riisom for collecting the cytotoxicity data for $(R)$ - and $(S)$-ispinesib.

\section{REFERENCES}

(1) Behera, M.; Owonikoko, T. K.; Kim, S.; Chen, Z.; Higgins, K.; Ramalingam, S. S.; Shin, D. M.; Khuri, F. R.; Beitler, J. J.; Saba, N. F. Concurrent therapy with taxane versus non-taxane containing regimens in locally advanced squamous cell carcinomas of the head and neck (SCCHN): a systematic review. Oral Oncol. 2014, 50 (9), 888-94.

(2) Crown, J.; O’Leary, M. The taxanes: an update. Lancet 2000, 355 (9210), 1176-8.

(3) McGrogan, B. T.; Gilmartin, B.; Carney, D. N.; McCann, A. Taxanes, microtubules and chemoresistant breast cancer. Biochim. Biophys. Acta, Rev. Cancer 2008, 1785 (2), 96-132.

(4) Shi, J.; Gao, P.; Song, Y.; Chen, X.; Li, Y.; Zhang, C.; Wang, H.; Wang, Z. Efficacy and safety of taxane-based systemic chemotherapy of advanced gastric cancer: A systematic review and meta-analysis. Sci. Rep. 2017, 7 (1), 5319.

(5) Socinski, M. A. Update on taxanes in the first-line treatment of advanced non-small-cell lung cancer. Curr. Oncol. 2014, 21 (5), 691703.

(6) Moudi, M.; Go, R.; Yien, C. Y.; Nazre, M. Vinca alkaloids. Int. J. Prev. Med. 2013, 4 (11), 1231-1235.

(7) Lipp, H.-P.; Hartmann, J. T.; Stanley, A., Cytostatic Drugs. In Side Effects of Drugs Annual 28; Aronson, J. K., Ed.; Elsevier, 2005; Vol. 28, pp 538-551.
(8) Fu, Y.; Li, S.; Zu, Y.; Yang, G.; Yang, Z.; Luo, M.; Jiang, S.; Wink, M.; Efferth, T. Medicinal chemistry of paclitaxel and its analogues. Curr. Med. Chem. 2009, 16 (30), 3966-85.

(9) Hayashi, Y.; Takeno, H.; Chinen, T.; Muguruma, K.; Okuyama, K.; Taguchi, A.; Takayama, K.; Yakushiji, F.; Miura, M.; Usui, T.; Hayashi, Y. Development of a new benzophenone-diketopiperazinetype potent antimicrotubule agent possessing a 2-pyridine structure. ACS Med. Chem. Lett. 2014, 5 (10), 1094-8.

(10) Nicholson, B.; Lloyd, G. K.; Miller, B. R.; Palladino, M. A.; Kiso, Y.; Hayashi, Y.; Neuteboom, S. T. C. NPI-2358 is a tubulindepolymerizing agent: In-vitro evidence for activity as a tumor vascular-disrupting agent. Anti-Cancer Drugs 2006, 17 (1), 25-31.

(11) Wieczorek, A.; Błauż, A.; Zakrzewski, J.; Rychlik, B.; Plażuk, D. Ferrocenyl 2,5-Piperazinediones as Tubulin-Binding Organometallic $\mathrm{ABCB} 1$ and ABCG2 Inhibitors Active against MDR Cells. ACS Med. Chem. Lett. 2016, 7 (6), 612-7.

(12) Wohl, A. R.; Michel, A. R.; Kalscheuer, S.; Macosko, C. W.; Panyam, J.; Hoye, T. R. Silicate esters of paclitaxel and docetaxel: synthesis, hydrophobicity, hydrolytic stability, cytotoxicity, and prodrug potential. J. Med. Chem. 2014, 57 (6), 2368-79.

(13) Wang, Y. F.; Shi, Q. W.; Dong, M.; Kiyota, H.; Gu, Y. C.; Cong, B. Natural taxanes: developments since 1828. Chem. Rev. 2011, 111 (12), 7652-709.

(14) Tischer, J.; Gergely, F. Anti-mitotic therapies in cancer. J. Cell Biol. 2019, 218 (1), 10-11.

(15) Paier, C. R. K.; Maranhão, S. S. A.; Carneiro, T. R.; Lima, L. M.; Rocha, D. D.; Santos, R. d. S.; Farias, K. M. d.; Moraes-Filho, M. O. d.; Pessoa, C. Natural products as new antimitotic compounds for anticancer drug development. Clinics (Sao Paulo) 2018, 73 (suppl 1), No. e813s.

(16) Marzo, I.; Naval, J. Antimitotic drugs in cancer chemotherapy: Promises and pitfalls. Biochem. Pharmacol. 2013, 86 (6), 703-710.

(17) Liu, Z.; Sun, Q.; Wang, X. PLK1, A Potential Target for Cancer Therapy. Transl. Oncol. 2017, 10 (1), 22-32.

(18) Bavetsias, V.; Linardopoulos, S. Aurora Kinase Inhibitors: Current Status and Outlook. Front. Oncol. 2015, 5, 278.

(19) Keen, N.; Taylor, S. Aurora-kinase inhibitors as anticancer agents. Nat. Rev. Cancer 2004, 4 (12), 927-36.

(20) Tang, A.; Gao, K.; Chu, L.; Zhang, R.; Yang, J.; Zheng, J. Aurora kinases: novel therapy targets in cancers. Oncotarget 2017, 8 (14), 23937-23954.

(21) Bowles, D. W.; Diamond, J. R.; Lam, E. T.; Weekes, C. D.; Astling, D. P.; Anderson, R. T.; Leong, S.; Gore, L.; Varella-Garcia, M.; Vogler, B. W.; Keysar, S. B.; Freas, E.; Aisner, D. L.; Ren, C.; Tan, A. C.; Wilhelm, F.; Maniar, M.; Eckhardt, S. G.; Messersmith, W. A.; Jimeno, A. Phase I study of oral rigosertib (ON 01910. Na), a dual inhibitor of the PI3K and Plk1 pathways, in adult patients with advanced solid malignancies. Clin. Cancer Res. 2014, 20 (6), 1656-65.

(22) Steegmaier, M.; Hoffmann, M.; Baum, A.; Lenart, P.; Petronczki, M.; Krssak, M.; Gurtler, U.; Garin-Chesa, P.; Lieb, S.; Quant, J.; Grauert, M.; Adolf, G. R.; Kraut, N.; Peters, J. M.; Rettig, W. J. BI 2536, a potent and selective inhibitor of polo-like kinase 1, inhibits tumor growth in vivo. Curr. Biol. 2007, 17 (4), 316-22.

(23) Mayer, T. U.; Kapoor, T. M.; Haggarty, S. J.; King, R. W.; Schreiber, S. L.; Mitchison, T. J. Small molecule inhibitor of mitotic spindle bipolarity identified in a phenotype-based screen. Science 1999, 286 (5441), 971-4.

(24) Holen, K.; DiPaola, R.; Liu, G.; Tan, A. R.; Wilding, G.; Hsu, K.; Agrawal, N.; Chen, C.; Xue, L.; Rosenberg, E.; Stein, M. A phase I trial of MK-0731, a kinesin spindle protein (KSP) inhibitor, in patients with solid tumors. Invest. New Drugs 2012, 30 (3), 1088-95.

(25) Ivachtchenko, A. V.; Kiselyov, A. S.; Tkachenko, S. E.; Ivanenkov, Y. A.; Balakin, K. V. Novel mitotic targets and their smallmolecule inhibitors. Curr. Cancer Drug Targets 2007, 7 (8), 766-784.

(26) Miglarese, M. R.; Carlson, R. O. Development of new cancer therapeutic agents targeting mitosis. Expert Opin. Invest. Drugs 2006, 15 (11), 1411-25.

(27) Lemieux, C.; DeWolf, W.; Voegtli, W.; Wallace, E.; Woessner, R.; Corrette, C.; Allen, S.; Hans, J.; Zhao, Q.; Aicher, T.; Lyssikatos, 
J.; Robinson, J.; Koch, K.; Winkler, J.; Gross, S. ARRY-520, a Novel, Highly Selective KSP Inhibitor with Potent Anti-Proliferative Activity. Blood 2006, 108, 4401.

(28) Purcell, J. W.; Davis, J.; Reddy, M.; Martin, S.; Samayoa, K.; Vo, H.; Thomsen, K.; Bean, P.; Kuo, W. L.; Ziyad, S.; Billig, J.; Feiler, H. S.; Gray, J. W.; Wood, K. W.; Cases, S. Activity of the kinesin spindle protein inhibitor ispinesib (SB-715992) in models of breast cancer. Clin. Cancer Res. 2010, 16 (2), 566-76.

(29) Bongero, D.; Paoluzzi, L.; Marchi, E.; Zullo, K. M.; Neisa, R.; Mao, Y.; Escandon, R.; Wood, K.; O'Connor, O. A. The novel kinesin spindle protein (KSP) inhibitor SB-743921 exhibits marked activity in in vivo and in vitro models of aggressive large B-cell lymphoma. Leuk. Lymphoma 2015, 56 (10), 2945-52.

(30) Jaouen, G.; Salmain, M. Bioorganometallic Chemistry; Wiley$\mathrm{VCH}, 2014$.

(31) Jaouen, G.; Vessieres, A.; Top, S. Ferrocifen type anti cancer drugs. Chem. Soc. Rev. 2015, 44 (24), 8802-17.

(32) Rilak Simovic, A.; Masnikosa, R.; Bratsos, I.; Alessio, E. Chemistry and reactivity of ruthenium (II) complexes: DNA/protein binding mode and anticancer activity are related to the complex structure. Coord. Chem. Rev. 2019, 398, 113011.

(33) Meier-Menches, S. M.; Gerner, C.; Berger, W.; Hartinger, C. G.; Keppler, B. K. Structure-activity relationships for ruthenium and osmium anticancer agents - towards clinical development. Chem. Soc. Rev. 2018, 47 (3), 909-928.

(34) Hanif, M.; Babak, M. V.; Hartinger, C. G. Development of anticancer agents: wizardry with osmium. Drug Discovery Today 2014, 19 (10), 1640-8.

(35) Geldmacher, Y.; Oleszak, M.; Sheldrick, W. S. Rhodium(III) and iridium(III) complexes as anticancer agents. Inorg. Chim. Acta 2012, 393, 84-102.

(36) Plażuk, D.; Wieczorek, A.; Błauż, A.; Rychlik, B. Synthesis and biological activities of ferrocenyl derivatives of paclitaxel. MedChemComm 2012, 3 (4), 498-501.

(37) Plażuk, D.; Wieczorek, A.; Ciszewski, W. M.; Kowalczyk, K.; Błauż, A.; Pawlędzio, S.; Makal, A.; Eurtivong, C.; Arabshahi, H. J.; Reynisson, J.; Hartinger, C. G.; Rychlik, B. Synthesis and in vitro Biological Evaluation of Ferrocenyl Side-Chain-Functionalized Paclitaxel Derivatives. ChemMedChem 2017, 12 (22), 1882-1892.

(38) Nicolaus, N.; Reball, J.; Velder, J.; Termath, A.; Schmalz, H.-G.; Sitnikov, N.; Yu. Fedorov, A. A Convenient Entry to New C-7Modified Colchicinoids through Azide Alkyne [3 + 2] Cycloaddition: Application of Ring-Contractive Rearrangements. Heterocycles 2010, 82 (2), 1585-1600.

(39) Nicolaus, N.; Zapke, J.; Riesterer, P.; Neudorfl, J. M.; Prokop, A.; Oschkinat, H.; Schmalz, H. G. Azides Derived from Colchicine and their Use in Library Synthesis: a Practical Entry to New Bioactive Derivatives of an Old Natural Drug. ChemMedChem 2010, 5 (5), 661-665.

(40) Kowalczyk, K.; Błauż, A.; Ciszewski, W. M.; Wieczorek, A.; Rychlik, B.; Plażuk, D. Colchicine metallocenyl bioconjugates showing high antiproliferative activities against cancer cell lines. Dalton Trans. 2017, 46 (48), 17041-17052.

(41) Kowalczyk, K.; Błauż, A.; Ciszewski, W. M.; Wieczorek, A.; Rychlik, B.; Plażuk, D. Correction: Colchicine metallocenyl bioconjugates showing high antiproliferative activities against cancer cell lines. Dalton Trans. 2018, 47 (8), 2822.

(42) Beauperin, M.; Polat, D.; Roudesly, F.; Top, S.; Vessieres, A.; Oble, J.; Jaouen, G.; Poli, G. Approach to ferrocenyl-podophyllotoxin analogs and their evaluation as anti-tumor agents. J. Organomet. Chem. 2017, 839, 83-90.

(43) Wieczorek, A.; Blauz, A.; Makal, A.; Rychlik, B.; Plazuk, D. Synthesis and evaluation of biological properties of ferrocenylpodophyllotoxin conjugates. Dalton Trans. 2017, 46 (33), 1084710858 .

(44) Wieczorek, A.; Błauż, A.; Zal, A.; Arabshahi, H. J.; Reynisson, J.; Hartinger, C. G.; Rychlik, B.; Plażuk, D. Ferrocenyl Paclitaxel and Docetaxel Derivatives: Impact of an Organometallic Moiety on the Mode of Action of Taxanes. Chem. - Eur. J. 2016, 22 (32), 11413-21.
(45) Bennett, M. A.; Smith, A. K. Arene Ruthenium(II) Complexes Formed by Dehydrogenation of Cyclohexadienes with Ruthenium(III) Trichloride. J. Chem. Soc., Dalton Trans. 1974, No. 2, 233-241.

(46) Kiel, W. A.; Ball, R. G.; Graham, W. A. G. Carbonyl- $\eta$ hexamethylbenzene complexes of osmium. Carbon-hydrogen activation by $(\eta$-C6Me6) Os $(\mathrm{CO})(\mathrm{H}) 2$. J. Organomet. Chem. 1990, 383 (1), 481-496.

(47) White, C.; Yates, A.; Maitlis, P.; Heinekey, D. ( $75-$ Pentamethylcyclopentadienyl) Rhodium and-Iridium Compounds. Inorg. Synt. 2007, 228-234.

(48) Holland, J. P.; Jones, M. W.; Cohrs, S.; Schibli, R.; Fischer, E. Fluorinated quinazolinones as potential radiotracers for imaging kinesin spindle protein expression. Bioorg. Med. Chem. 2013, 21 (2), 496-507.

(49) Mészáros, J. P.; Dömötör, O.; Hackl, C. M.; Roller, A.; Keppler, B. K.; Kandioller, W.; Enyedy, É. A. Structural and solution equilibrium studies on half-sandwich organorhodium complexes of (N, N) donor bidentate ligands. New J. Chem. 2018, 42 (13), 1117411184

(50) Pizarro, A. M.; Habtemariam, A.; Sadler, P. J. Activation mechanisms for organometallic anticancer complexes. In Medicinal Organometallic Chemistry; Springer, 2010; pp 21-56.

(51) Babak, M. V.; Meier, S. M.; Legin, A. A.; Adib Razavi, M. S.; Roller, A.; Jakupec, M. A.; Keppler, B. K.; Hartinger, C. G. $\mathrm{Am}(\mathrm{m})$ ines Make the Difference: Organoruthenium $\mathrm{Am}(\mathrm{m})$ ine Complexes and Their Chemistry in Anticancer Drug Development. Chem. - Eur. J. 2013, 19 (13), 4308-4318.

(52) Kubanik, M.; Holtkamp, H.; Söhnel, T.; Jamieson, S. M. F.; Hartinger, C. G. Impact of the Halogen Substitution Pattern on the Biological Activity of Organoruthenium 8-Hydroxyquinoline Anticancer Agents. Organometallics 2015, 34 (23), 5658-5668.

(53) Kurzwernhart, A.; Kandioller, W.; Enyedy, E. A.; Novak, M.; Jakupec, M. A.; Keppler, B. K.; Hartinger, C. G. 3-Hydroxyflavones vs. 3-hydroxyquinolinones: structure-activity relationships and stability studies on $\mathrm{Ru}(\mathrm{II})$ (arene) anticancer complexes with biologically active ligands. Dalton Trans. 2013, 42 (17), 6193-202.

(54) Hanif, M.; Meier, S. M.; Kandioller, W.; Bytzek, A.; Hejl, M.; Hartinger, C. G.; Nazarov, A. A.; Arion, V. B.; Jakupec, M. A.; Dyson, P. J.; Keppler, B. K. From hydrolytically labile to hydrolytically stable $\mathrm{Ru}(\mathrm{II})$-arene anticancer complexes with carbohydrate-derived coligands. J. Inorg. Biochem. 2011, 105 (2), 224-31.

(55) El-Nassan, H. B. Advances in the discovery of kinesin spindle protein (Eg5) inhibitors as antitumor agents. Eur. J. Med. Chem. 2013, $62,614-31$.

(56) Matsuno, K.; Sawada, J.; Asai, A. Therapeutic potential of mitotic kinesin inhibitors in cancer. Expert Opin. Ther. Pat. 2008, 18 (3), 253-274.

(57) Carol, H.; Lock, R.; Houghton, P. J.; Morton, C. L.; Kolb, E. A.; Gorlick, R.; Reynolds, C. P.; Maris, J. M.; Keir, S. T.; Billups, C. A.; Smith, M. A. Initial testing (stage 1) of the kinesin spindle protein inhibitor ispinesib by the pediatric preclinical testing program. Pediatr. Blood Cancer 2009, 53 (7), 1255-1263.

(58) Al-Masoudi, W. A.; Al-Masoudi, N. A.; Weibert, B.; Winter, R. Synthesis, X-ray structure, in vitro HIV and kinesin Eg5 inhibition activities of new arene ruthenium complexes of pyrimidine analogs. $J$. Coord. Chem. 2017, 70 (12), 2061-2073.

(59) Al-Masoudi, W. A.; Al-Masoudi, N. A. A ruthenium complexes of monastrol and its pyrimidine analogues: Synthesis and biological properties. Phosphorus, Sulfur Silicon Relat. Elem. 2019, 194 (11), $1020-1027$.

(60) Talapatra, S. K.; Schuttelkopf, A. W.; Kozielski, F. The structure of the ternary Eg5-ADP-ispinesib complex. Acta Crystallogr., Sect. D: Biol. Crystallogr. 2012, 68 (10), 1311-1319.

(61) Zhang, B.; Liu, J.-F.; Xu, Y.; Ng, S.-C. Crystal structure of HsEg5 in complex with clinical candidate CK0238273 provides insight into inhibitory mechanism, potency, and specificity. Biochem. Biophys. Res. Commun. 2008, 372 (4), 565-570. 
(62) Myers, S. M.; Collins, I. Recent findings and future directions for interpolar mitotic kinesin inhibitors in cancer therapy. Future Med. Chem. 2016, 8 (4), 463-89.

(63) Rashid, U.; Hassan, S. F.; Nazir, S.; Wadood, A.; Waseem, M.; Ansari, F. L. Synthesis, docking studies, and in silico ADMET predictions of some new derivatives of pyrimidine as potential KSP inhibitors. Med. Chem. Res. 2015, 24 (1), 304-315.

(64) Park, H. W.; Ma, Z.; Zhu, H.; Jiang, S.; Robinson, R. C.; Endow, S. A. Structural basis of small molecule ATPase inhibition of a human mitotic kinesin motor protein. Sci. Rep. 2017, 7 (1), 15121.

(65) Chai, L.-Q.; Liu, G.; Zhang, Y.-L.; Huang, J.-J.; Tong, J.-F. Synthesis, crystal structure, fluorescence, electrochemical property, and SOD-like activity of an unexpected nickel (II) complex with a quinazoline-type ligand. J. Coord. Chem. 2013, 66 (22), 3926-3938.

(66) Batinić-Haberle, I.; Rebouças, J. S.; Spasojević, I. Superoxide dismutase mimics: chemistry, pharmacology, and therapeutic potential. Antioxid. Redox Signaling 2010, 13 (6), 877-918.

(67) Re, R.; Pellegrini, N.; Proteggente, A.; Pannala, A.; Yang, M.; Rice-Evans, C. Antioxidant activity applying an improved ABTS radical cation decolorization assay. Free Radical Biol. Med. 1999, 26 (9), 1231-1237.

(68) Błauż, A.; Rychlik, B. Drug-selected cell line panels for evaluation of the pharmacokinetic consequences of multidrug resistance proteins. J. Pharmacol. Toxicol. Methods 2017, 84, 57-65.

(69) Crooke, S. T.; Snyder, R. M.; Butt, T. R.; Ecker, D. J.; Allaudeen, H. S.; Monia, B.; Mirabelli, C. K. Cellular and molecular pharmacology of auranofin and related gold complexes. Biochem. Pharmacol. 1986, 35 (20), 3423-3431.

(70) Ishikawa, T.; Ali-Osman, F. Glutathione-associated cisdiamminedichloroplatinum(II) metabolism and ATP-dependent efflux from leukemia cells. Molecular characterization of glutathione-platinum complex and its biological significance. J. Biol. Chem. 1993, 268 (27), 20116-20125. 